NBER WORKING PAPER SERIES

\title{
WHAT'S WRONG WITH PITTSBURGH? DELEGATED INVESTORS AND LIQUIDITY CONCENTRATION
}

\author{
Andra C. Ghent \\ Working Paper 25966 \\ http://www.nber.org/papers/w25966 \\ NATIONAL BUREAU OF ECONOMIC RESEARCH \\ 1050 Massachusetts Avenue \\ Cambridge, MA 02138 \\ June 2019
}

The Real Estate Research Institute (RERI) provided generous financial support for this paper in the form of a research award of $\$ 15,000$. That support in no way influenced the findings in this paper. I am also grateful to Briana Chang, Bob Connolly, Jim Costello, Mike Eriksen, Valentin Haddad, Lu Han, Tim Landvoigt, Jack Liebersohn, Joe Pagliari, Kaveh Pahlevan, Jacob Sagi, Eva Steiner, Selale Tuzel, and Stijn Van Nieuwerburgh for helpful comments and conversations as well as conference and seminar participants at the AREUEA-ASSA Annual meeting, the Chicago Alternative Investments Research Conference, the Conference on Urban and Regional Economics (CURE), Cornell University, the Federal Reserve Board / George Washington University, the Miami Behavioral Finance Conference, the NBER Conference on New Developments in Long-Term Asset Management, the pre-WFA Real Estate Research Symposium, the RERI Annual Conference, the Rena Sivitandou Annual Research Symposium, Syracuse University, the University of British Columbia, the University of Miami, the University of Southern California, and the University of Wisconsin-Madison for comments. I thank CBRE and Real Capital Analytics for providing data. Joshua Graf provided excellent research assistance. The views expressed herein are those of the author and do not necessarily reflect the views of the National Bureau of Economic Research.

NBER working papers are circulated for discussion and comment purposes. They have not been peer-reviewed or been subject to the review by the NBER Board of Directors that accompanies official NBER publications.

(C) 2019 by Andra C. Ghent. All rights reserved. Short sections of text, not to exceed two paragraphs, may be quoted without explicit permission provided that full credit, including () notice, is given to the source. 
What's Wrong with Pittsburgh? Delegated Investors and Liquidity Concentration Andra C. Ghent

NBER Working Paper No. 25966

June 2019

JEL No. G11,G12,G23,R33

\begin{abstract}
$\underline{\text { ABSTRACT }}$
What makes an asset institutional-quality? This paper proposes that one reason is the existing concentration of delegated investors in a market through a liquidity channel. Consistent with this intuition, it documents differences in investor composition across US cities and shows that delegated investors concentrate investments in cities with higher turnover. It then calibrates a search model showing how heterogeneity in liquidity preferences makes some markets more liquid even when assets have identical cash flows. The calibration indicates that commercial real estate commands an illiquidity premium of two percentage points annually relative to a perfectly liquid asset with similar credit risk.
\end{abstract}

\author{
Andra C. Ghent \\ Department of Real Estate and \\ Urban Land Economics \\ Wisconsin School of Business \\ University of Wisconsin - Madison \\ Madison, WI \\ ghent@wisc.edu
}




\section{Introduction}

As Table 1 shows, delegated investors don't find Pittsburgh attractive. While the share of commercial real estate (CRE) purchases by delegated investors averages $24 \%$ across US cities, it is a mere $14 \%$ in Pittsburgh. What makes Pittsburgh so much less attractive than other cities? More generally, what makes some assets appropriate for delegated managers and not others?

This paper argues that one reason delegated managers focus on some assets is the concentration of other institutions in that market. I start from the observation that some types of investors trade frequently while others are more likely to be buy-and-hold investors. The key intuition is that investors that value liquidity the most concentrate their investments in the most liquid markets. In so doing, they give up an illiquidity premium. Thus, concern for liquidity segments markets by investor type. The market segmentation in turn makes the most liquid markets even more liquid because the main asset owners are those that trade relatively more frequently. To the extent that delegated managers are more likely to have higher illiquidity needs than direct investors, an asset's attractiveness to delegated mangers depends on the existing concentration of delegated managers in an asset.

This paper provides evidence on the relationship between investor composition and trade frequency in CRE consistent with this explanation. I use a dataset on all commercial property transactions in 39 cities over the 2001-2015 period that enables classification of purchasers by type and, in particular, identification of delegated investors. In the CRE market, investors managing their own money are more likely to play the role of buy-and-hold investors than are delegated investors. ${ }^{1}$ Consistent with delegated investors having relatively more need for liquidity, they have shorter holding periods than non-delegated investors (i.e., direct investors) on average. Controlling for property characteristics, year of purchase, and the Metropolitan Statistical Area (MSA) of the property, delegated investors on average hold properties about one year less than direct investors. The difference is most pronounced for private equity funds but is also statistically significant for investment managers and banks.

\footnotetext{
${ }^{1}$ I treat Real Estate Investment Trusts (REITs) separately from other delegated investors because REITs must satisfy statutory minimum holding period requirements to be eligible for tax-exempt status.
} 
Table 1: Average Share of Purchases by Delegated Investors and REITs by MSA

\begin{tabular}{|c|c|c|c|c|c|c|c|}
\hline Rank & msa & msalabel & $\begin{array}{c}\text { (1) } \\
\text { delshare } \\
\text { Purchases } \\
2001-2015\end{array}$ & $\begin{array}{c}(2) \\
\text { delshare } \\
\text { Purchases } \\
2001-2007\end{array}$ & $\begin{array}{c}\text { (3) } \\
\text { delshare } \\
\text { Purchases } \\
2008-2015\end{array}$ & $\begin{array}{c}(4) \\
\text { delshare } \\
\text { Sales } \\
\text { 2001-2015 }\end{array}$ & $\begin{array}{c}\text { (5) } \\
\text { sharereit } \\
\text { Purchases } \\
2001-2015\end{array}$ \\
\hline 1 & Boston & $\mathrm{BOS}$ & 38.6 & 44.5 & 33.4 & 37.2 & 13.4 \\
\hline 2 & DC Metro & $\mathrm{DC}$ & 36.3 & 38.0 & 34.9 & 34.1 & 20.2 \\
\hline 3 & Seattle & STL & 35.1 & 35.3 & 34.9 & 29.5 & 13.3 \\
\hline 4 & San Francisco & $\mathrm{SFO}$ & 33.2 & 34.0 & 32.5 & 37.7 & 11.9 \\
\hline 5 & Chicago & $\mathrm{CHI}$ & 31.0 & 33.7 & 28.5 & 33.4 & 17.0 \\
\hline 6 & Memphis & MEM & 30.7 & 27.7 & 33.3 & 25.0 & 19.4 \\
\hline 7 & Dallas & DFW & 29.3 & 32.7 & 26.4 & 30.0 & 17.1 \\
\hline 8 & Austin & AUS & 29.0 & 26.6 & 31.1 & 30.0 & 16.0 \\
\hline 9 & Atlanta & ATL & 28.9 & 27.5 & 30.1 & 24.5 & 17.8 \\
\hline 10 & Denver & DEN & 28.6 & 26.9 & 30.0 & 29.5 & 16.2 \\
\hline 11 & San Jose & SJC & 27.9 & 26.0 & 29.6 & 25.7 & 10.9 \\
\hline 12 & Minneapolis & MSP & 27.7 & 26.6 & 28.6 & 23.1 & 23.7 \\
\hline 13 & Indianapolis & IND & 27.6 & 29.1 & 26.3 & 25.0 & 20.7 \\
\hline 14 & Columbus & $\mathrm{CMH}$ & 27.3 & 21.1 & 32.7 & 20.5 & 19.0 \\
\hline 15 & Baltimore & BWI & 26.6 & 23.0 & 29.7 & 23.6 & 26.7 \\
\hline 16 & Houston & $\mathrm{HOU}$ & 26.5 & 26.7 & 26.3 & 31.8 & 21.9 \\
\hline 17 & Oakland & OAK & 26.0 & 28.7 & 23.6 & 28.9 & 11.9 \\
\hline 18 & San Diego & SAN & 25.4 & 26.3 & 24.6 & 26.8 & 13.8 \\
\hline 19 & Cincinnati & $\mathrm{CIN}$ & 24.6 & 25.3 & 23.9 & 19.6 & 28.9 \\
\hline 20 & Portland & PDX & 23.8 & 29.8 & 18.5 & 21.8 & 12.6 \\
\hline 21 & Orange County & $\mathrm{OC}$ & 23.5 & 22.9 & 24.1 & 25.1 & 8.8 \\
\hline 22 & Los Angeles & LA & 22.8 & 27.1 & 19.0 & 23.0 & 9.5 \\
\hline 23 & Orlando & $\mathrm{MCO}$ & 22.6 & 20.8 & 24.2 & 18.8 & 22.8 \\
\hline 24 & Charlotte & CLT & 22.0 & 20.3 & 23.5 & 20.5 & 19.0 \\
\hline 25 & Nashville & BNA & 21.7 & 21.2 & 22.2 & 19.2 & 20.5 \\
\hline 26 & Tampa & TPA & 21.2 & 18.7 & 23.4 & 23.9 & 16.5 \\
\hline 27 & Riverside & RIV & 21.0 & 20.2 & 21.6 & 19.9 & 11.4 \\
\hline 28 & Kansas City & $\mathrm{KC}$ & 20.6 & 21.6 & 19.7 & 19.1 & 22.5 \\
\hline 29 & NYC Metro & NYC & 20.5 & 22.3 & 18.9 & 23.7 & 16.0 \\
\hline 30 & Sacramento & $\mathrm{SAC}$ & 19.0 & 26.0 & 12.9 & 17.4 & 10.9 \\
\hline 31 & Phoenix & PHX & 17.5 & 19.8 & 15.4 & 19.4 & 18.1 \\
\hline 32 & Philadelphia & PHL & 16.7 & 16.2 & 17.1 & 26.6 & 19.4 \\
\hline 33 & Salt Lake City & $\mathrm{SLC}$ & 16.4 & 16.9 & 16.0 & 14.2 & 14.8 \\
\hline 34 & Jacksonville & JAX & 16.2 & 10.4 & 21.3 & 20.4 & 21.4 \\
\hline 35 & Las Vegas & LAS & 15.9 & 12.1 & 19.2 & 11.5 & 13.6 \\
\hline 36 & San Antonio & SAT & 14.3 & 11.0 & 17.3 & 21.6 & 19.6 \\
\hline 37 & Pittsburgh & PIT & 14.3 & 12.5 & 15.9 & 13.7 & 17.9 \\
\hline 38 & Cleveland & CLE & 12.0 & 9.8 & 13.9 & 15.5 & 19.3 \\
\hline 39 & Detroit & DTW & 9.6 & 6.8 & 12.0 & 17.4 & 13.0 \\
\hline Average & & & 23.9 & 23.8 & 24.0 & 23.8 & 17.1 \\
\hline Median & & & 23.8 & 25.3 & 23.9 & 23.6 & 17.1 \\
\hline
\end{tabular}

Notes: 1) delshare is the share of commercial real estate transactions made by delegated investors. 2) In columns (1)-(3) and (5), the shares are based on the identity of the buyer in the transaction; in column (4), the share is based on the identity of the seller in the transaction. 3) Delegated investors are entities that primarily manage money on behalf of others and include banks, pension funds, investment managers, and private equity funds. 4) sharereit is the share of purchases made by Real Estate Investment Trusts (REITs). 5) Shares are by $\$$ volume not number of transactions. 6) Data for all cities except Pittsburgh and San Antonio covers 2001-2015. Data for Pittsburgh and San Antonio covers 2002-2015 and 2007-2015, respectively. 
Furthermore, a CRE purchase is more likely to be made by a delegated than a direct investor in markets with higher turnover even after controlling for property-level characteristics and the economic fundamentals of an MSA. A one standard deviation increase in the trade frequency in an MSA increases the likelihood the purchaser is a delegated investor by about $6 \%$. Consistent with these transaction-level results, the share of delegated investors among all investors is higher in markets with more trade frequency. Finally, dividend yields are higher in markets with less trade frequency consistent with assets in such markets commanding illiquidity premia.

The paper considers several competing explanations for delegated investors' choice of cities. Most prominently, delegated investors have a preference for what are known as 'credit tenants'. That is, delegated investors want to own buildings where the tenants are publicly listed firms such that they are effectively exposed to cash flow risk similar to that of a corporate bond. To consider differences in the concentration of publicly listed firms across cities, I use detailed establishment-level employment data to compute the share of employment in a city of publicly listed firms. There is a relationship between the importance of publicly listed firms and the share of purchases made by delegated investors at the MSAlevel. However, at the level of an individual transaction, there is no relationship between the share of employment by publicly listed firms and whether the transaction is made by a delegated investor. There is also strong MSA-level evidence that delegated investors prefer cities with higher shares of college-educated workers. I also find that, within an MSA, increases in trade frequency over time are associated with a higher delegated investor share.

The paper then calibrates the directed search model of Vayanos and Wang (2007), which features investors that are heterogeneous in the frequency with which they receive valuation shocks, to the US CRE market. The model illustrates how market segmentation by liquidity preference amplifies cross-market differences in liquidity. The model can replicate the large differences in trade frequency across cities and modest difference in cap rates. Quantitatively, the model generates an illiquidity premium for investing in US CRE of about two percentage points per year.

The findings illustrate that there is path dependence in what different types of in- 
vestors consider investible. Many delegated managers express a desire to increase their allocations to alternative asset classes but then assert that such product does not exist. One characteristic of the asset that makes it institutional quality is in fact the concentration of other institutions in that market due to the implications for liquidity of investor composition. As such, the findings in this paper suggest that it will be difficult for delegated investors to rapidly change their allocations to alternatives including real estate. This difficulty in increasing allocations to alternatives may lead to even further increases in the share of publicly traded equities held by institutional investors. ${ }^{2}$

The results also suggest that there may be path dependence in the development of cities to the extent that delegated investors have preferences over property characteristics other than liquidity. Delegated investors tend to purchase larger properties than direct investors, for example, and, within an MSA, buy higher-quality properties. Initial differences in a city's investor base may thus manifest in long-term differences in a city's urban design and, thus, the types of households and firms in a city. Stein (1989) highlights the inefficiency that may result from managers' short-termism. Recent work on publicly traded firms has also shown that investors with shorter holding periods invest in firms less committed to social and environmental responsibility (Starks et al. (2018)). It is thus plausible that the shorter expected holding periods of delegated investors in a city may lead them to shy away from long-term investments in a city's infrastructure and work force.

While I focus on the model of Vayanos and Wang (2007), the intuition that liquidity begets liquidity appears in other theories of OTC markets. For example, the models of Admati and Pfleiderer (1988) and Pagano (1989) generate such a prediction and Biais and Green (2007) discuss how endogenous liquidity has led to bonds usually trading OTC since the mid-20th century. ${ }^{3}$ More recently, Chang (2018) presents a model where submarkets with different trade frequencies arise endogenously as a result of heterogeneity in traders' holding costs.

\footnotetext{
${ }^{2}$ See Andonov and Rauh (2018) regarding pension funds' allocations to real estate and non-real estate private equity. Koijen and Yogo (Forthcoming) show that the share of publicly traded equities held by institutions rose from $35 \%$ in the $1980-1984$ period to $68 \%$ in the $2015-2017$ period.

${ }^{3}$ Plante (2017) nevertheless shows that there would be significant welfare gains to moving corporate bond trading to an exchange-traded platform.
} 
Finally, the paper adds to a body of work that explains facts about real estate markets using search and matching models. While a number of papers have used search and matching models to understand the housing market (see Han and Strange (2015) for a summary of early literature), the only other papers that study the CRE market using a search and matching model are Sagi (2017) and Badarinza et al. (2018). While Sagi (2017) explains the returns on individual properties with a search model, the current paper aims to explain heterogeneity across cities in CRE trade volumes and investor composition. Badarinza et al. (2018) uses a search model to quantify how search frictions arising from differences in investor

nationality affect cross-border capital flows. Instead of studying the effects of heterogeneity in nationality, I study the effects of heterogeneity in the frequency of valuation shocks.

The next section of the paper describes the data in detail including differences in the types of properties that delegated investors, direct investors, REITs, and small investors purchase. Section 3 shows that, relative to direct investors, delegated investors have shorter holding periods and purchase properties in higher turnover markets. Section 4 calibrates the Vayanos and Wang (2007) model to the US CRE market to explain the aforementioned facts. Section 5 concludes and discusses potential future research.

\section{Data and Investor Type Classification}

\subsection{CRE Transactions Data}

The data covers 2001-2015 for 39 US MSAs. 2001 is the first year for which Real Capital Analytics (RCA) has transactions data. It includes all cities and years for which data on transactions and the stock of CRE are available that can also be merged to Census data using a standardized definition of an MSA. In some cases (e.g., South Florida), the data provider's definition of a market cannot be matched to a standard MSA definition making it difficult to merge the data with other data sources and I exclude such cities. RCA provided data on every purchase transaction in these 39 cities in industrial, retail, and office property. The sample of 115,734 observations covers more than $99 \%$ of CRE transactions in these cities 
over 2001-2015.

A key advantage of the RCA data relative to, for example, deeds records, is RCA's ownership information. RCA standardizes buyer names and invests substantial resources in identifying the true buyer behind a transaction with a legal identity that is perhaps only an LLC that is not obviously linked to the actual owner. I classify purchases by buyers who made less than five purchases over the entire sample period simply as SMALL due to difficulties in accurately classifying such buyers. Buyers who make less than five purchases account for approximate $53 \%$ of all transactions by number but only $26 \%$ of transactions by dollar amount. Buyers with five or more transactions make a total of 54,600 transactions.

The data RCA provided contained the variables BuyerCapGroup 1 and SellerCapGroup1 that classified buyers and sellers into groups such as "Institutional", "Private", and "Public". These variables assisted with the classification but were not sufficiently detailed for this study since, for example, many private firms are delegated asset managers. I classify each buyer into one of the following nine types of investors: Banks (BANK), Developer/Owner/Operators (DEVOWNOP), Investment Managers (INVM), Private Equity Funds (PEFU), REITs (REIT), Pension Funds (PENS), Users (USER), Real Estate Operating Companies (REOC), and Other (OTH). I follow RCA in grouping Developer/Owner/Operators into a single category, DEVOWNOP, as firms often undertake one or more of these functions and it is difficult to clearly distinguish between the three categories.

In the case of BANK, REIT, PENS, and REOC, the classification is fairly unambiguous. The distinction between DEVOWNOP and INVM or PEFU is whether the entity is managing its own funds or those of other parties. The reason for this distinction is that the friction that gives delegated investors shorter holding periods is an agency friction between investors and managers. There is some ambiguity in whether to classify an entity as INVM

\footnotetext{
${ }^{4}$ The sample RCA provided contained 116,307 observations which are all purchases of CRE in the 39 markets in industrial, retail, and office property over 2001-2015. This sample excludes entity-level purchases (i.e., property company mergers, approximately 3000 observations) and observations in which the interest conveyed was not 100\% (approximately 4000 observations). 549 observations had missing data on the number of square feet. Excluding these observations reduced the sample size to 115,758. Of the remaining observations, 23 had a price per square foot of less than $\$ 1$ suggesting the transactions were not arms-length and one observation had a property size of just 8 square feet suggesting a data entry error. Deleting these observations resulted in a dataset of 115,734 observations.
} 
or PEFU but, as both are delegated investors, the distinction does not matter for most of the analysis in this paper. I categorize entities that have multiple business lines and cannot be clearly categorized as either a DEVOWNOP or INVM/PEFU as OTH.

Figure 1 provides the shares of purchases made by each category of investors at the national level aggregated across all years, i.e., when I aggregate the data set across all 39 cities in the sample. The shares shown are based on the dollar volume of transactions, not the number of transactions. The single largest category is DEVOWNOP at $27 \%$ of all purchases. PEFU and INVM combined account for an additional $21 \%$ while REITs purchase $15 \%$ of property. Users account for an additional $2 \%$ of transactions while banks purchased 4\%. Pension funds' direct purchases constitute only $2 \%$ of purchases each with the Other category accounting for less than $1 \% .^{5}$

\section{Delegated Investors}

I group investors into four categories: delegated investors, direct investors, REITs, and small investors. I hypothesize that delegated investors have shorter holding periods than direct investors because of agency frictions. Because principals cannot observe the effort and skill level of managers, they require managers to dispose of the investments in a timely fashion. ${ }^{6}$ The information asymmetry is especially acute in commercial real estate because of the heterogeneity in properties and the infrequency with which properties trade. Delegated investors may also have to dispose of a property before receiving all of their compensation from the principal. Given large discrepancies between appraisal and transaction prices (see Cannon and Cole (2011)), it's not feasible to compensate managers based on appraisal values. I separate REITs from other delegated investors because REITs have long holding periods by statute; see Mühlhofer (2019) regarding REIT holding period constraints being binding. I

\footnotetext{
${ }^{5}$ The share of CRE purchases by pension funds may seem small. The share shown only captures investments in which the pension fund is the owner of record such that it excludes many joint ventures as well as any indirect CRE investment by pension funds. See Andonov et al. (2015) for additional discussion of the CRE investments of pension funds.

${ }^{6}$ Chakraborty and Ewens (2018) provide evidence from venture capital firms of agents delaying revealing negative information. Such agency conflicts necessitate contracts that incentivize delegated managers to dispose of investments in a timely fashion. Stein (1989) discusses several possible reasons delegated managers may have greater liquidity needs than principals.
} 
Figure 1: Investor Composition in US Commercial Real Estate, 2001-2015
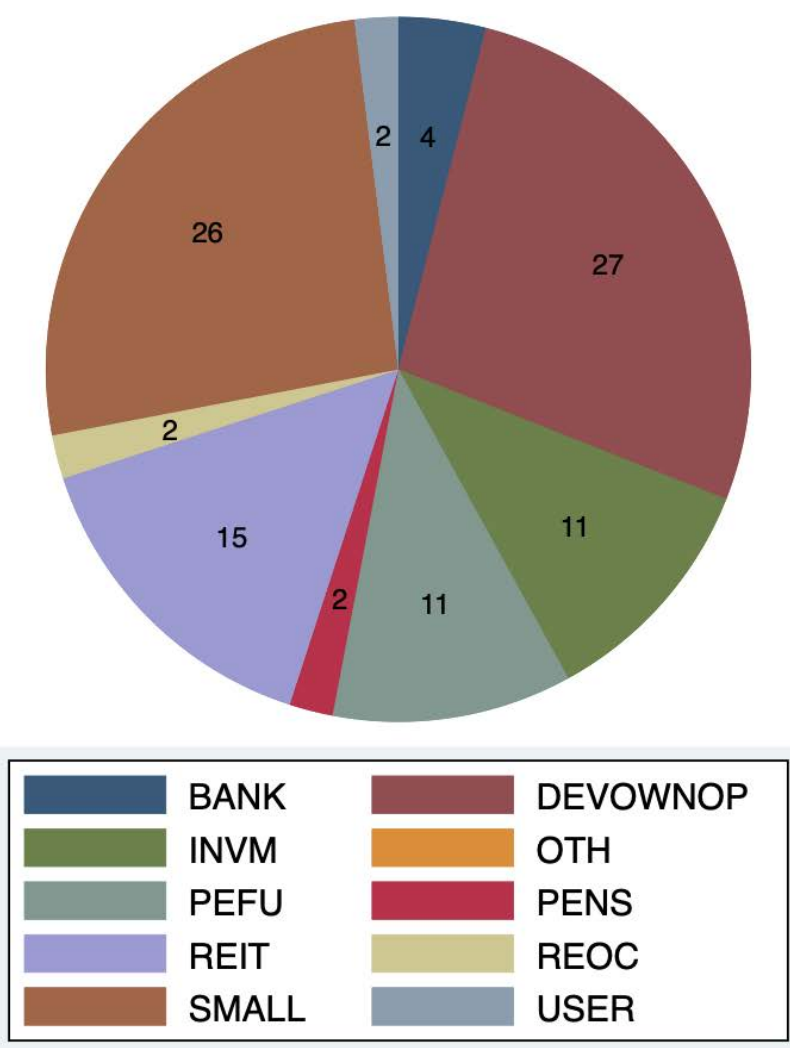

Notes: 1) DEV denotes Developer/Owner/Operator, INVM denotes Investment Manager, PEFU denotes Private Equity Fund, PENS denotes Pension Fund, REOC denotes Real Estate Operating Company, OTH denotes Other, and SMALL denotes a buyer that makes less than five transactions over the full sample period. 2) Investor type shares are averaged over 2001-2015 and are value-weighted. 
consider BANK, PEFU, INVM, and PENS as delegated investors. The remaining non-REIT investor types I consider direct investors.

\section{Property Characteristics}

In addition to the buyer name, transaction price, and square footage, for most properties RCA provided the year the property was built, and the property's national and local QScores. The RCA Q-Scores are proprietary measures of a property's relative quality varying from 1 to 100. They are more detailed alternatives to descriptors such as "Class A" or "Class C". The "scores incorporate not only physical attributes, but also market and locational factors". Costello (2017) provides additional discussion of the RCA Q-Scores. I present the relationship between investor composition and trade frequency both controlling and not controlling for them. To better understand what types of investors are most likely to undertake development, I create a variable called development that takes a value of 1 if the property is less than 1 year old. Finally, office, industrial, and retail are indicator variables for the property type.

Table 2 summarizes the property-level variables. Figures 2, 3, 4, and 5 show the distributions of property size (square footage), property age, and quality across the three different investor types. Consistent with the summary statistics in Panels B and C of Table 2, the biggest difference between the types of properties delegated and direct investors purchase is in size. Properties purchased by delegated investors are about 75,000 square feet larger on average than properties purchased by direct investors, a difference that is highly statistically significant in a univariate t-test for the difference in means. Not surprisingly, small investors overwhelmingly own physically small properties.

Delegated investors also invest in slightly younger properties on average. On average, properties purchased by delegated investors are about seven years younger and the difference is highly statistically significant in a univariate t-test for the difference in means. A fatter

right tail primarily drives the difference in the mean property age between delegated and direct investors. The difference between the medians is only three years while the difference rises to 30 years at the 90 th percentile. As Table 2 shows, there is no substantial difference 
Table 2: Transaction-Level Summary Statistics

\begin{tabular}{|c|c|c|c|c|c|c|}
\hline & Obs. & Mean & Median & Std. Dev. & Min. & Max \\
\hline \multicolumn{7}{|c|}{ Panel A: All Transactions } \\
\hline YearBlt & 109,082 & 1978.3 & 1985.0 & 26.7 & 1111.0 & 2020.0 \\
\hline Price & 115,734 & $\$ 15,000,000$ & $\$ 5,695,875$ & $\$ 42,800,000$ & $\$ 23,484$ & $\$ 2,950,000,000$ \\
\hline Units & 115,734 & 106.8 & 53.0 & 172.5 & 0.6 & 5500.0 \\
\hline QScoreLocal & 97,593 & 0.51 & 0.51 & 0.29 & 0 & 1 \\
\hline QScoreNat & 97,593 & 0.57 & 0.59 & 0.29 & 0 & 1 \\
\hline development & 115,734 & 0.02 & 0 & 0.15 & 0 & 1 \\
\hline office & 115,734 & 0.33 & 0 & 0.47 & 0 & 1 \\
\hline industrial & 115,734 & 0.35 & 0 & 0.48 & 0 & 1 \\
\hline retail & 115,734 & 0.31 & 0 & 0.46 & 0 & 1 \\
\hline \multicolumn{7}{|c|}{ Panel B: Delegated Investor Purchases } \\
\hline YearBlt & 14,116 & 1984.2 & 1987.0 & 21.9 & 1803.0 & 2020.0 \\
\hline Price & 14,872 & $\$ 33,000,000$ & $\$ 14,000,000$ & $\$ 68,400,000$ & $\$ 196,237$ & $\$ 2,200,000,000$ \\
\hline Units & 14,872 & 205.7 & 128.8 & 235.5 & 1.3 & 3787.2 \\
\hline QScoreLocal & 11,126 & 0.54 & 0.55 & 0.28 & 0 & 1 \\
\hline QScoreNat & 11,126 & 0.55 & 0.55 & 0.28 & 0 & 1 \\
\hline development & 14,872 & 0.02 & 0 & 0.14 & 0 & 1 \\
\hline office & 14,872 & 0.43 & 0 & 0.49 & 0 & 1 \\
\hline industrial & 14,872 & 0.41 & 0 & 0.49 & 0 & 1 \\
\hline retail & 14,872 & 0.16 & 0 & 0.37 & 0 & 1 \\
\hline \multicolumn{7}{|c|}{ Panel C: Direct Investor Purchases } \\
\hline YearBlt & 27,972 & 1977.2 & 1984.0 & 26.9 & 1708.0 & 2018.0 \\
\hline Price & 29,372 & $\$ 18,500,000$ & $\$ 8,150,000$ & $\$ 47,200,000$ & $\$ 44,472$ & $\$ 2,950,000,000$ \\
\hline Units & 29,372 & 129.2 & 75.3 & 188.3 & 0.7 & 5500.0 \\
\hline QScoreLocal & 24,395 & 0.48 & 0.46 & 0.29 & 0 & 1 \\
\hline QScoreNat & 24,395 & 0.54 & 0.55 & 0.30 & 0 & 1 \\
\hline development & 29,372 & 0.02 & 0 & 0.13 & 0 & 1 \\
\hline office & 29,372 & 0.36 & 0 & 0.48 & 0 & 1 \\
\hline industrial & 29,372 & 0.30 & 0 & 0.46 & 0 & 1 \\
\hline retail & 29,372 & 0.34 & 0 & 0.47 & 0 & 1 \\
\hline \multicolumn{7}{|c|}{ Panel D: REIT Purchases } \\
\hline YearBlt & 9,584 & 1987.5 & 1990.0 & 20.2 & 1635.0 & 2016.0 \\
\hline Price & 10,356 & $\$ 25,200,000$ & $\$ 11,200,000$ & $\$ 66,500,000$ & $\$ 112,548$ & $\$ 2,800,000,000$ \\
\hline Units & 10,356 & 158.6 & 98.1 & 214.0 & 1.2 & 4348.1 \\
\hline QScoreLocal & 7,982 & 0.58 & 0.60 & 0.28 & 0 & 1 \\
\hline QScoreNat & 7,982 & 0.56 & 0.57 & 0.27 & 0 & 1 \\
\hline development & 10,356 & 0.03 & 0 & 0.17 & 0 & 1 \\
\hline office & 10,356 & 0.27 & 0 & 0.44 & 0 & 1 \\
\hline industrial & 10,356 & 0.33 & 0 & 0.47 & 0 & 1 \\
\hline retail & 10,356 & 0.40 & 0 & 0.49 & 0 & 1 \\
\hline \multicolumn{7}{|c|}{ Panel E: Small Investor Purchases } \\
\hline YearBlt & 57,410 & 1975.8 & 1983.0 & 28.1 & 1111.0 & 2018.0 \\
\hline Price & 61,134 & $\$ 7,266,014$ & $\$ 4,010,000$ & $\$ 18,600,000$ & $\$ 23,484$ & $\$ 1,250,000,000$ \\
\hline Units & 61,134 & 63.1 & 32.8 & 114.2 & 0.6 & 5400.0 \\
\hline QScoreLocal & 54,090 & 0.50 & 0.50 & 0.30 & 0 & 1 \\
\hline QScoreNat & 54,090 & 0.58 & 0.62 & 0.30 & 0 & 1 \\
\hline development & 61,134 & 0.02 & 0 & 0.15 & 0 & 1 \\
\hline office & 61,134 & 0.30 & 0 & 0.46 & 0 & 1 \\
\hline industrial & 61,134 & 0.37 & 0 & 0.48 & 0 & 1 \\
\hline retail & 61,134 & 0.33 & 0 & 0.47 & 0 & 1 \\
\hline
\end{tabular}

Notes: 1) YearBlt is the year the property was built or is anticipated to be completed in the case or properties still under development. 2) Units is the number of square feet in 1000s. 3) QScoreLocal and QScoreNat are proprietary RCA measures of the quality of the property relative to other properties in that MSA and in the Nation, respectively. 4) development takes a value of 1 if the property is under one year of age at the time of purchase. 
between delegated and direct investors in the share of development properties.

QScoreLocal is about six percentage points higher for delegated than for direct investors indicating that delegated investors buy higher quality properties than direct investors within an MSA. However, there is not a substantial difference between QScoreNat.

Figure 2: Property Size (Square Feet in 1000s) for 2001-2015 Purchases by Investor Type

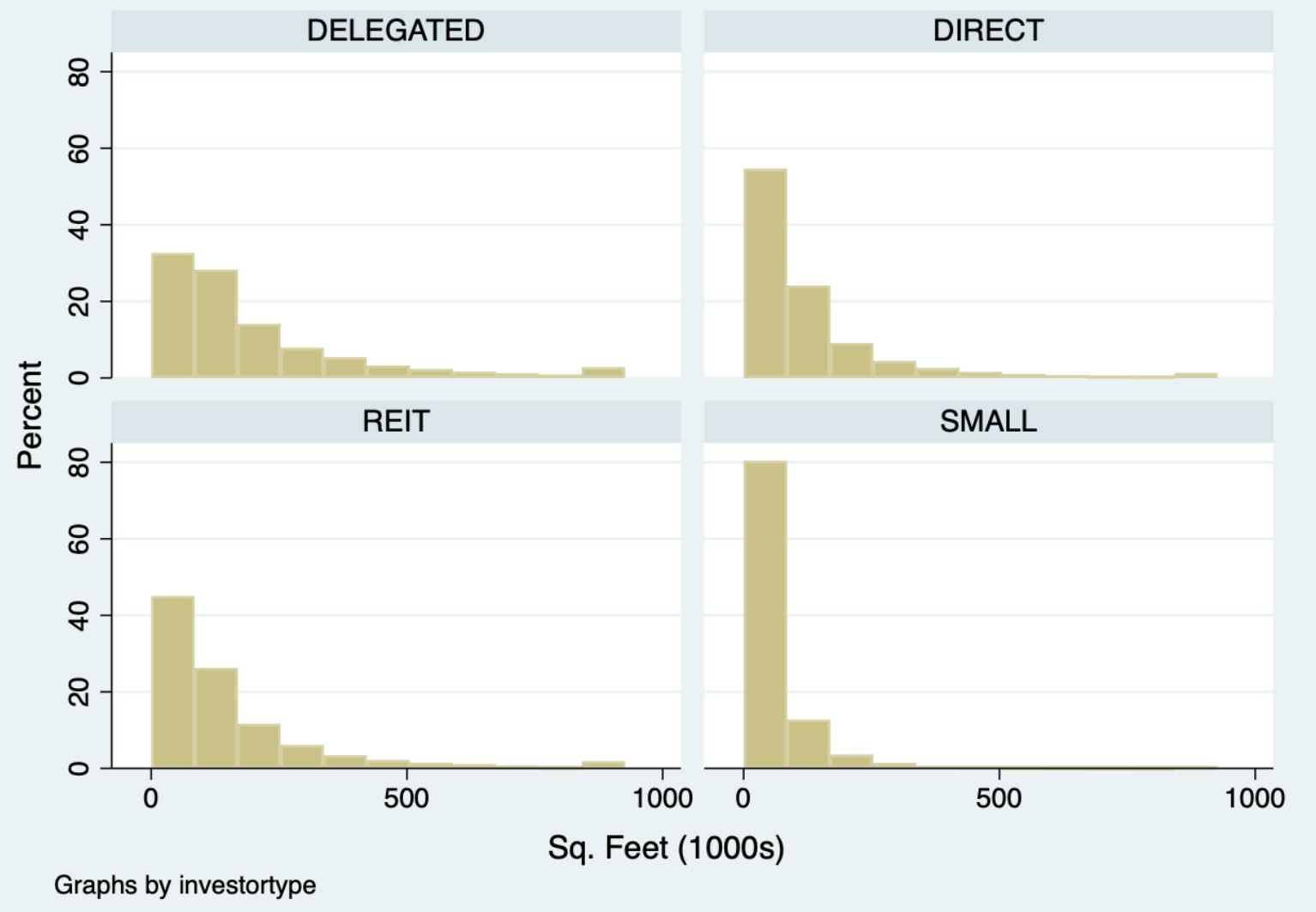

Notes: 1) DELEGATED includes banks, investment managers, private equity funds, and pension funds. 2) SMALL investors are investors with less than five transactions over the sample period. 3) I winsorize the right tail at the $1 \%$ level due to a handful of outliers.

\subsection{MSA Characteristics}

\section{Potential Credit Tenants}

A key potential driver of delegated investors' decisions regarding which cities to invest in is the availability of credit tenants. Credit tenants are generally nationally known publicly traded firms and delegated investors may have a preference for such tenants because they 
Figure 3: Property Age for 2001-2015 Purchases by Investor Type

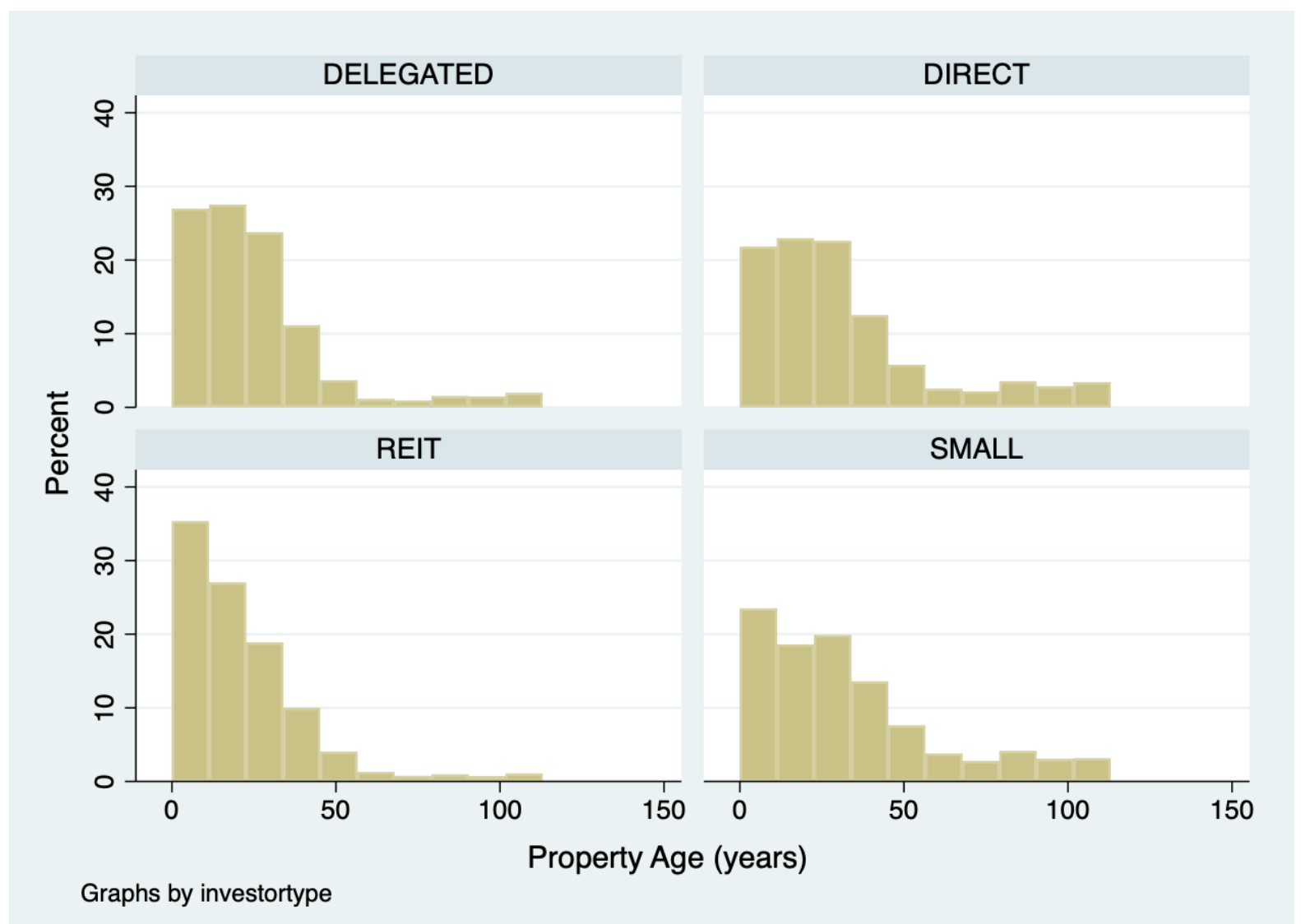

Notes: 1) DELEGATED includes banks, investment managers, private equity funds, and pension funds. 2) SMALL investors are investors with less than five transactions over the sample period. 3) Property age measured in years. 4) I winsorize the right tail at the $1 \%$ level due to a handful of outliers. 
Figure 4: Within MSA Property Quality for 2001-2015 Purchases by Investor Type

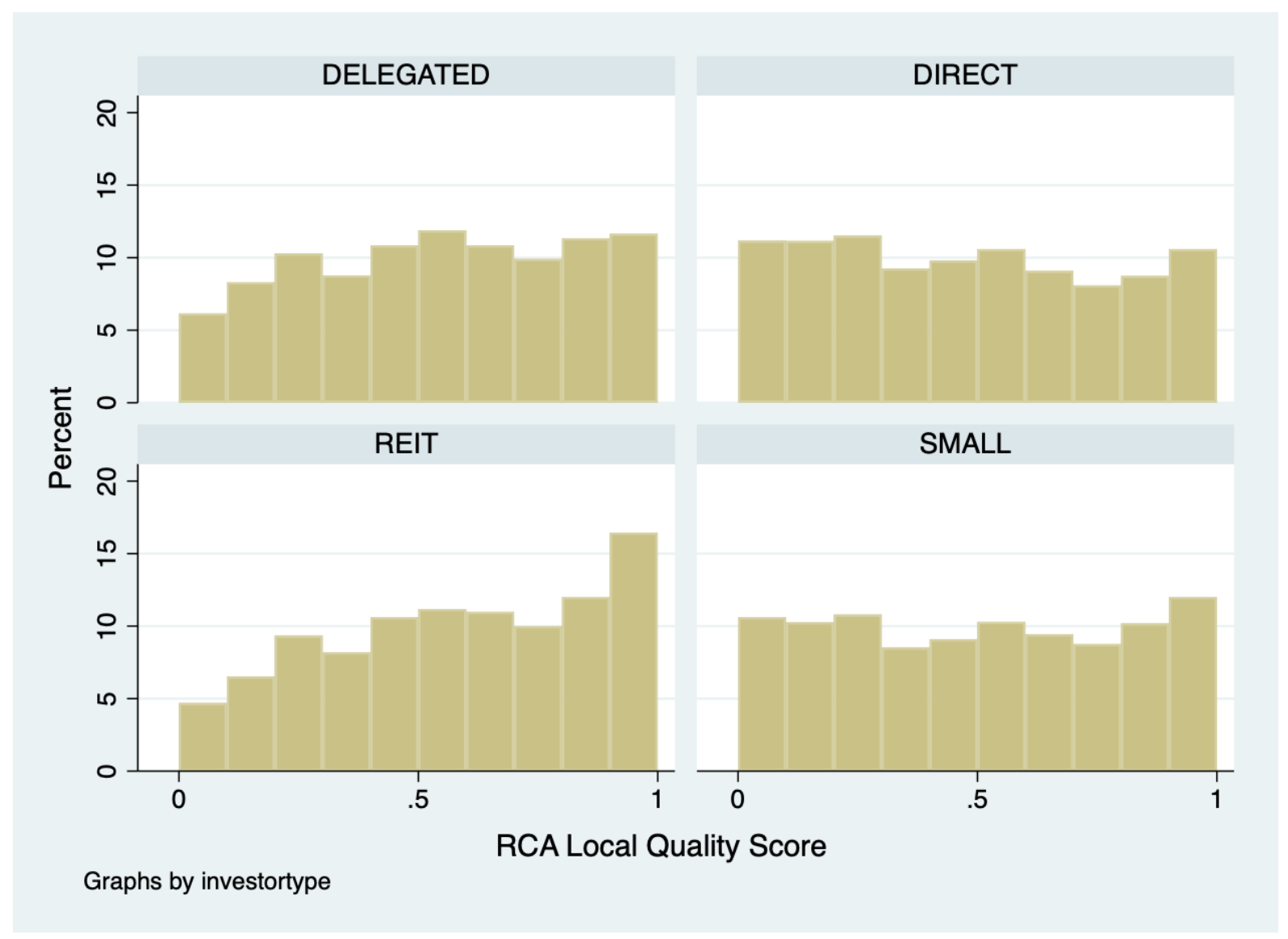

Notes: 1) DELEGATED includes banks, investment managers, private equity funds, and pension funds. 2) SMALL investors are investors with less than five transactions over the sample period. 3) Property quality is a proprietary metric constructed by RCA; see Costello (2017) for details. 
Figure 5: National Property Quality for 2001-2015 Purchases by Investor Type

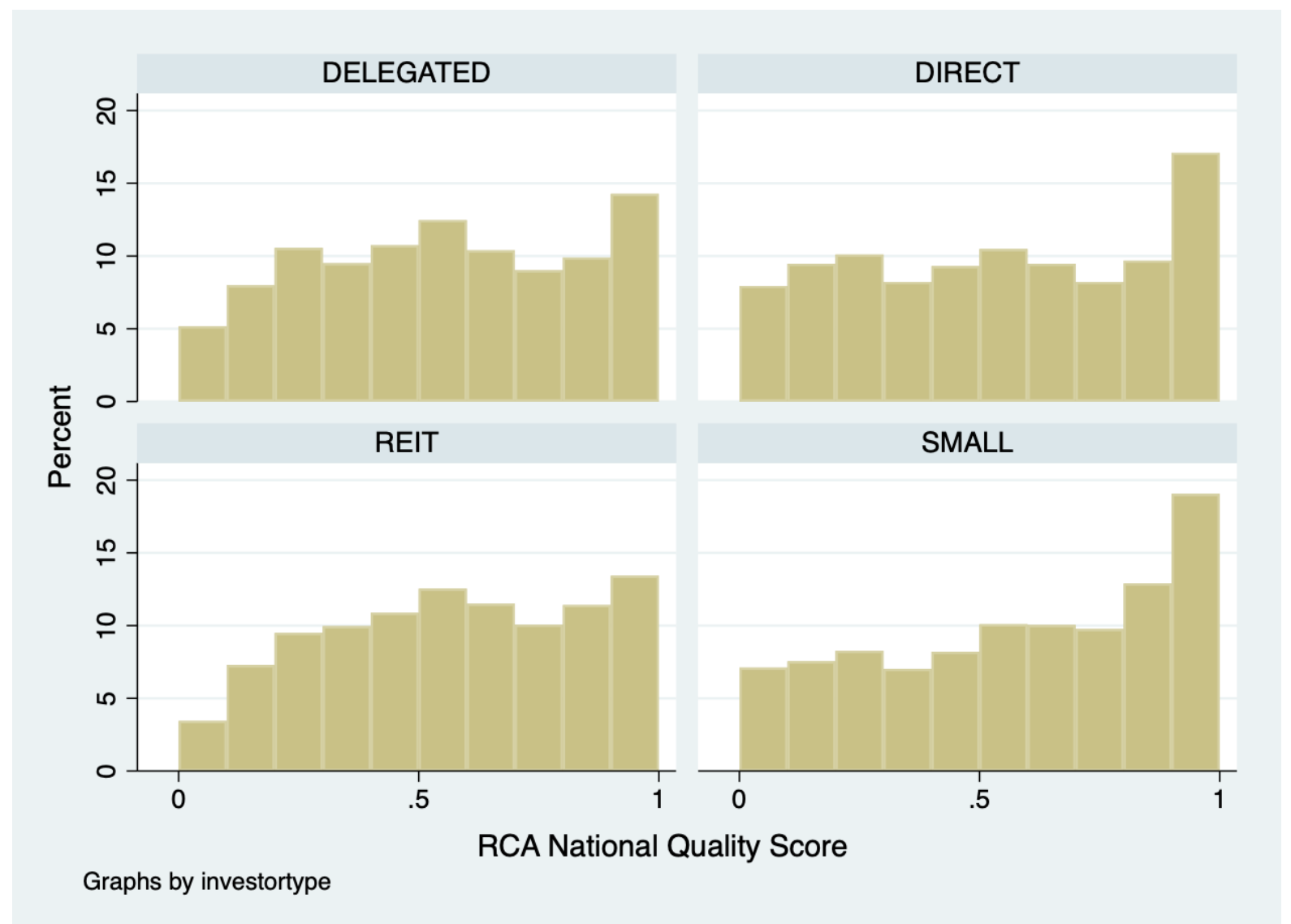

Notes: 1) DELEGATED includes banks, investment managers, private equity funds, and pension funds. 2) SMALL investors are investors with less than five transactions over the sample period. 3) Property quality is a proprietary metric constructed by RCA; see Costello (2017) for details. 
can readily show measures of credit-worthiness to their investment boards. The argument is similar to the 'prudent-man' laws Del Guercio (1996) shows affect the choice of equity holdings of institutional investors. I compute the assets of publicly traded firms headquartered in an MSA in each year from Compustat. I take the natural log of these to get logfirmassets.

However, the headquarters of a firm is not where all their economic activity takes place; see García and Norli (2012). I therefore also use establishment-level employment data from Your-economy Time Series (YTS) to identify the share of employment in an MSA that is from publicly traded firms. The underlying data for YTS is the Infogroup Historic Datafiles. The data is an annual establishment-level time series database that follows companies at their unique locations across the US. YTS focuses on establishments that are "in-business" in the sense that it filters out firms that are created for tax purposes or merely holding companies. Additional details on the YTS data, and how it compares with other establishment-level employment data, are available at http://bdrc.uwex.edu/downloads/YTSdatadescription.pdf and http://bdrc.uwex.edu/insights/YTSreview.pdf.

The YTS data provide linking codes that link establishments to the headquarters firm. I identify publicly traded firms by whether they have a stock ticker symbol in the YTS data. Averaging across 2001-2015, the YTS data reveal that about $72 \%$ of the average publicly traded firm's employment is in the same Core-Based Statistical Area (CBSA) as the firm's headquarters. However, the share is much smaller for large firms such that weighting by total firm employment rather than equally-weighting firms results in a much larger share of employment outside of a firm's headquarters CBSA. Of all employment in publicly traded firms, only about $17 \%$ is in the same CBSA as the firm's headquarters.

To get a measure of the availability of credit tenants in an MSA, I aggregate all the employment in establishments linked to publicly traded firms and divide it by the total employment in the MSA. I denote this variable pubempshare. Table 3 ranks the cities in the sample according to the share of employment by publicly traded firms. 
Table 3: US Cities' Economic Fundamentals

MSAs Ranked by Share of MSA Employment in Publicly Traded Firms

\begin{tabular}{|c|c|c|c|c|c|c|}
\hline Rank & $\overline{\mathrm{msa}}$ & $\bar{~} \overline{\text { msalabel }}$ & pubempshare & estsperemp & $\overline{\mathrm{e} e m p_{-} H H I}$ & $\overline{c \text { college }}$ \\
\hline 1 & Las Vegas & LAS & 24.4 & 0.067 & 0.091 & 19.9 \\
\hline 2 & San Jose & SJC & 22.6 & 0.077 & 0.075 & 43.7 \\
\hline 3 & Memphis & MEM & 20.6 & 0.078 & 0.068 & 23.8 \\
\hline 4 & Cincinnati & $\mathrm{CIN}$ & 19.9 & 0.071 & 0.067 & 26.4 \\
\hline 5 & Indianapolis & IND & 19.4 & 0.071 & 0.070 & 29.2 \\
\hline 6 & Atlanta & ATL & 19.2 & 0.085 & 0.064 & 34.3 \\
\hline 7 & Dallas & DFW & 18.9 & 0.081 & 0.064 & 30.0 \\
\hline 8 & Orlando & $\mathrm{MCO}$ & 18.9 & 0.082 & 0.073 & 26.6 \\
\hline 9 & Denver & DEN & 18.6 & 0.083 & 0.062 & 36.8 \\
\hline 10 & Phoenix & PHX & 18.5 & 0.078 & 0.065 & 26.7 \\
\hline 11 & Houston & $\mathrm{HOU}$ & 18.4 & 0.082 & 0.063 & 27.9 \\
\hline 12 & Nashville & BNA & 17.9 & 0.081 & 0.074 & 28.3 \\
\hline 13 & Kansas City & $\mathrm{KC}$ & 17.7 & 0.073 & 0.068 & 32.0 \\
\hline 14 & Minneapolis & MSP & 17.3 & 0.066 & 0.068 & 37.0 \\
\hline 15 & Jacksonville & JAX & 17.0 & 0.086 & 0.068 & 26.3 \\
\hline 16 & Charlotte & CLT & 16.9 & 0.084 & 0.062 & 30.3 \\
\hline 17 & Tampa & TPA & 16.7 & 0.088 & 0.073 & 24.6 \\
\hline 18 & Columbus & $\mathrm{CMH}$ & 16.5 & 0.066 & 0.077 & 32.0 \\
\hline 19 & Salt Lake City & SLC & 16.3 & 0.071 & 0.065 & 28.5 \\
\hline 20 & Chicago & $\mathrm{CHI}$ & 16.2 & 0.077 & 0.065 & 32.1 \\
\hline 21 & Seattle & STL & 16.0 & 0.086 & 0.069 & 35.8 \\
\hline 22 & San Francisco & $\mathrm{SFO}$ & 15.5 & 0.091 & 0.067 & 43.1 \\
\hline 23 & Oakland & OAK & 15.5 & 0.091 & 0.067 & 43.1 \\
\hline 24 & San Antonio & $\mathrm{SAT}$ & 15.5 & 0.084 & 0.072 & 24.2 \\
\hline 25 & Detroit & DTW & 15.1 & 0.080 & 0.074 & 26.3 \\
\hline 26 & Portland & PDX & 14.9 & 0.089 & 0.067 & 31.9 \\
\hline 27 & Cleveland & CLE & 14.7 & 0.074 & 0.073 & 26.7 \\
\hline 28 & Pittsburgh & PIT & 14.7 & 0.084 & 0.076 & 27.1 \\
\hline 29 & Riverside & RIV & 14.4 & 0.093 & 0.069 & 18.9 \\
\hline 30 & San Diego & SAN & 14.3 & 0.084 & 0.069 & 33.9 \\
\hline 31 & Austin & AUS & 14.2 & 0.084 & 0.068 & 39.1 \\
\hline 32 & DC Metro & $\mathrm{DC}$ & 14.0 & 0.076 & 0.073 & 46.0 \\
\hline 33 & Orange County & $\mathrm{OC}$ & 13.8 & 0.093 & 0.065 & 29.3 \\
\hline 34 & Los Angeles & $\mathrm{LA}$ & 13.8 & 0.093 & 0.065 & 29.3 \\
\hline 35 & Philadelphia & PHL & 13.8 & 0.082 & 0.072 & 31.6 \\
\hline 36 & Baltimore & BWI & 13.5 & 0.082 & 0.075 & 33.1 \\
\hline 37 & Sacramento & $\mathrm{SAC}$ & 13.2 & 0.091 & 0.072 & 29.9 \\
\hline 38 & Boston & BOS & 13.1 & 0.081 & 0.073 & 40.5 \\
\hline 39 & NYC Metro & NYC & 11.7 & 0.090 & 0.069 & 34.9 \\
\hline
\end{tabular}

Notes: 1) pubempshare is the fraction of employees in an MSA employed by a publicly traded firm. 2) Calculations of pubempshare, emp_HHI, and estsperemp based on establishment-level data provided by YTS. 3) pubempshare, emp_HHI, and estsperemp are averaged over 2001-2015 period. 4) college is the share of the population with a college degree from the 2005 American Community Survey. 


\section{Other MSA-Level Economic Fundamentals}

I also use the YTS data to measure industry concentration in each city and the overall level of competitiveness of firms. I measure the industry concentration in each city by constructing the Herfendahl-Hirschman Index (HHI) using establishment-level employment in 2-digit NAICS code industries. I term this variable emp_HHI. I construct the overall degree of competition between firms in a city by dividing the total employment in a city by the number of establishments (estsperemp).

The Bureau of Economic Analysis (BEA) provides real GDP at the MSA-level from 2001 onwards from which I calculate GDP growth for 2002 onwards. I take the share of the population with a four-year college degree or more education (college) from the 2005 American Community Survey (ACS). I take the population of the MSA from the 2010 US Census.

\section{Property Market Variables}

RCA also provides data on capitalization (cap) rates. CRE investors use the term cap rate to refer to the dividend yield of a property. I use these data to calibrate the model of Section 4. CBRE, a major CRE brokerage firm, provides the data on the stock of commercial real estate by MSA. Information on the stock in Pittsburgh and San Antonio starts only in 2002 and 2007 such that the samples are shorter for these cities. CBRE also provides data on occupancy rates and rent growth by property type and MSA.

\section{Empirical Facts}

\subsection{Delegated Investors Have Shorter Holding Periods than Di- rect Investors}

Table 4 provides univariate statistics on holding periods of delegated and direct investors. For Table 4 only, I code transactions that have not sold by the end of the property as having a holding period of 15; I recode this as 14 for the Tobit regressions in Table 5. The first panel 
shows all transactions and illustrates a modest difference in the overall holding periods. On average, delegated investors hold their properties 0.6 years less. The small difference in the full sample is largely because most properties have still not sold by the end of the sample. However, the 25th percentile of the holding period for delegated investors is 6 years which is two years less than the 25th percentile for direct investors. The second panel includes only purchases made in 2001-2003, such that there is time for the investor to have sold the property before the end of the sample. For the 2001-2003 transactions, the median holding period for delegated investors in 6 years while it is 12 for direct investors.

Table 4: Holding Periods of Direct and Delegated Investors

\begin{tabular}{lccccccc}
\hline \hline & mean & $\mathrm{p} 25$ & $\mathrm{p} 50$ & $\mathrm{sd}$ & $\min$ & $\max$ & $\mathrm{n}$ \\
\hline 2001-2015 & Purchases & & & & & \\
Direct & 11.7 & 8 & 15 & 5.2 & 0 & 15 & 29,372 \\
Delegated & 11.1 & 6 & 15 & 5.4 & 0 & 15 & 14,872 \\
All & 11.5 & 7 & 15 & 5.3 & 0 & 15 & 44,244 \\
\hline 2001-2003 & Purchases & Only & & & & \\
Direct & 9.9 & 4 & 12 & 5.4 & 0 & 15 & 2,933 \\
Delegated & 8.0 & 3 & 6 & 5.3 & 0 & 15 & 1,289 \\
Total & 9.3 & 4 & 10 & 5.4 & 0 & 15 & 4,222 \\
\hline \hline
\end{tabular}

Table 5 shows that delegated investors have shorter holding periods even after controlling for which city they invest in, the year of purchase, and various property characteristics. I also control for the total dollar volume of transactions by the purchaser. The table presents Tobit regressions of the holding period on whether the purchaser is a delegated investor. The regression includes all transactions by delegated and direct investors; it excludes transactions by REITs and SMALL investors.

The first three columns of Table 5 present results for all years. In column 1, the only controls are year fixed effects. The coefficient on delegated is -0.64 and statistically significant at the $1 \%$ level. The specification in column 2 adds MSA fixed effects, a full set of property-level controls, and controls for buyer size. The coefficient is -0.66 , very close to the specification without any controls, and is statistically significant at the $1 \%$ level. Column 3 disaggregates delegated into the delegated subcategories invm, pefu, bank, and pens. The coefficient on pefu is highest at -1.09 while those on invm and bank are about -0.3. All 
three of these coefficients are statistically significant at the $5 \%$ level. The coefficient on pens is, however, small and statistically insignificant suggesting that pension funds may be less susceptible to liquidity shocks than other types of delegated managers.

Column 4 presents the coefficient estimates from the regression when I include only properties that are sold by the end of the sample. In this specification, I include only purchases from 2001-2003. The coefficient on delegated falls slightly but remains statistically significant at the $1 \%$ level. As such, the overall effect found in columns $1-3$ is driven both by direct investors being less likely to have sold a property by the end of the sample and by them having held on longer to properties they bought at the beginning of the sample and have since disposed of.

The last four columns present results for purchases made in 2001-2003, 2004-2006, 2007-2009, and 2010-2015 separately. In all specifications, the coefficient on delegated is negative and statistically significant at the $1 \%$ level. 


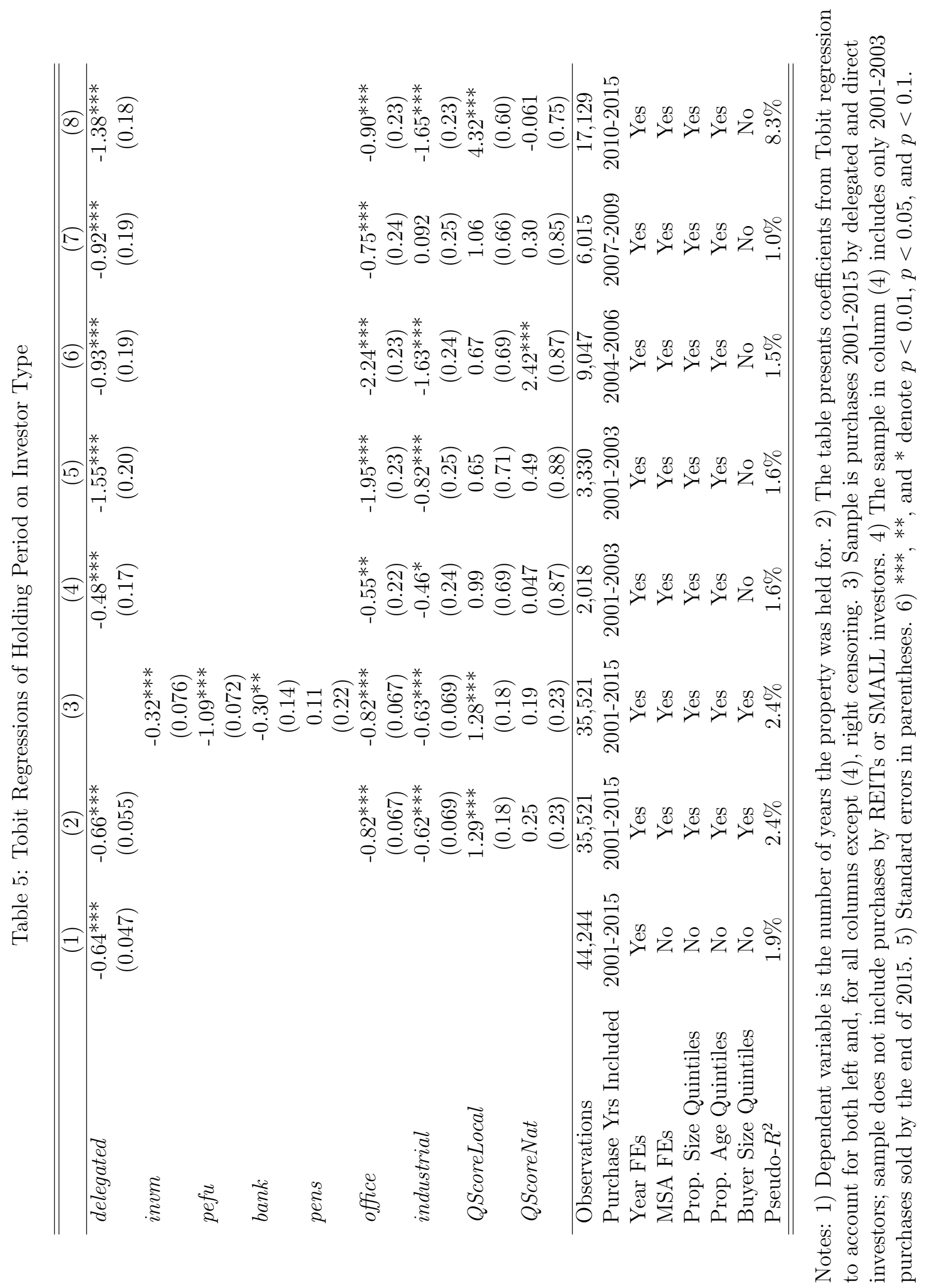




\subsection{Trade Frequency and Investor Composition}

\subsubsection{MSA-Level Relationships}

Table 1 aggregates the data across years to show how investor type shares range across MSAs. The table presents the average shares of purchases by delegated investors and REITs in each MSA over the 2001-2015 period. Delegated investors comprised 39\% of purchases in the Boston metro area but only 10\% of purchases in Detroit. Perhaps surprisingly, delegated investors accounted for less than the median share in the NYC Metro area. While delegated investors concentrate their purchases in coastal cities, Chicago and Dallas also have high shares of purchases by delegated investors.

The second and third columns of Table 1 show the shares of purchases by delegated investors over the first half and second half of the sample. While the shares change somewhat over time, there is substantial persistence. Table 6 illustrates this more formally. The table presents the regression coefficients from a regression of the share in the second half of the sample on the first half of the sample. The coefficient is 0.58. Perhaps even more striking, the $R^{2}$ of $53 \%$ shows that a city' historical investor composition explains more than half of its recent composition.

Table 6: Persistence of Delegated Investor Share Over Time

\begin{tabular}{lc}
\hline \hline & delsh $2008-2015$ \\
\hline delsh 2001-2007 & $0.58^{* * *}$ \\
& $(0.091)$ \\
Constant & $10.3^{* * *}$ \\
& $(2.27)$ \\
\hline Observations & 39 \\
$R^{2}$ & $52.5 \%$ \\
\hline \hline
\end{tabular}

Notes: 1) Standard errors in parentheses. 2) ${ }^{* * *}$ indicates $\left.p<0.01 .3\right)$ Dependent variable is share of purchases by delegated investors in MSA averaged 2008-2015.

Figure 6 illustrates that there is a positive relationship between ownership by delegated investors and trade frequency but does not control for any covariates. As the model of the next section shows, the causality between investor composition and trade frequency runs both ways rather than the positive relationship being solely because delegated investors 
choose markets with higher trade frequency. That is, trade frequency and investor composition are jointly determined such that a positive relationship between a market's delegated investor share and trade frequency is an equilibrium outcome. Nevertheless, it is worth considering a few explanations for the empirical relationship between the share of purchases by delegated investors and trade frequency other than the one this paper proposes. While an exhaustive empirical analysis of the determinants of ownership of CRE is beyond the scope of this paper, I consider several alternative explanations for the relationship in Figure 6.

Figure 6: Delegated Investor Share and Trade Frequency are Positively Related

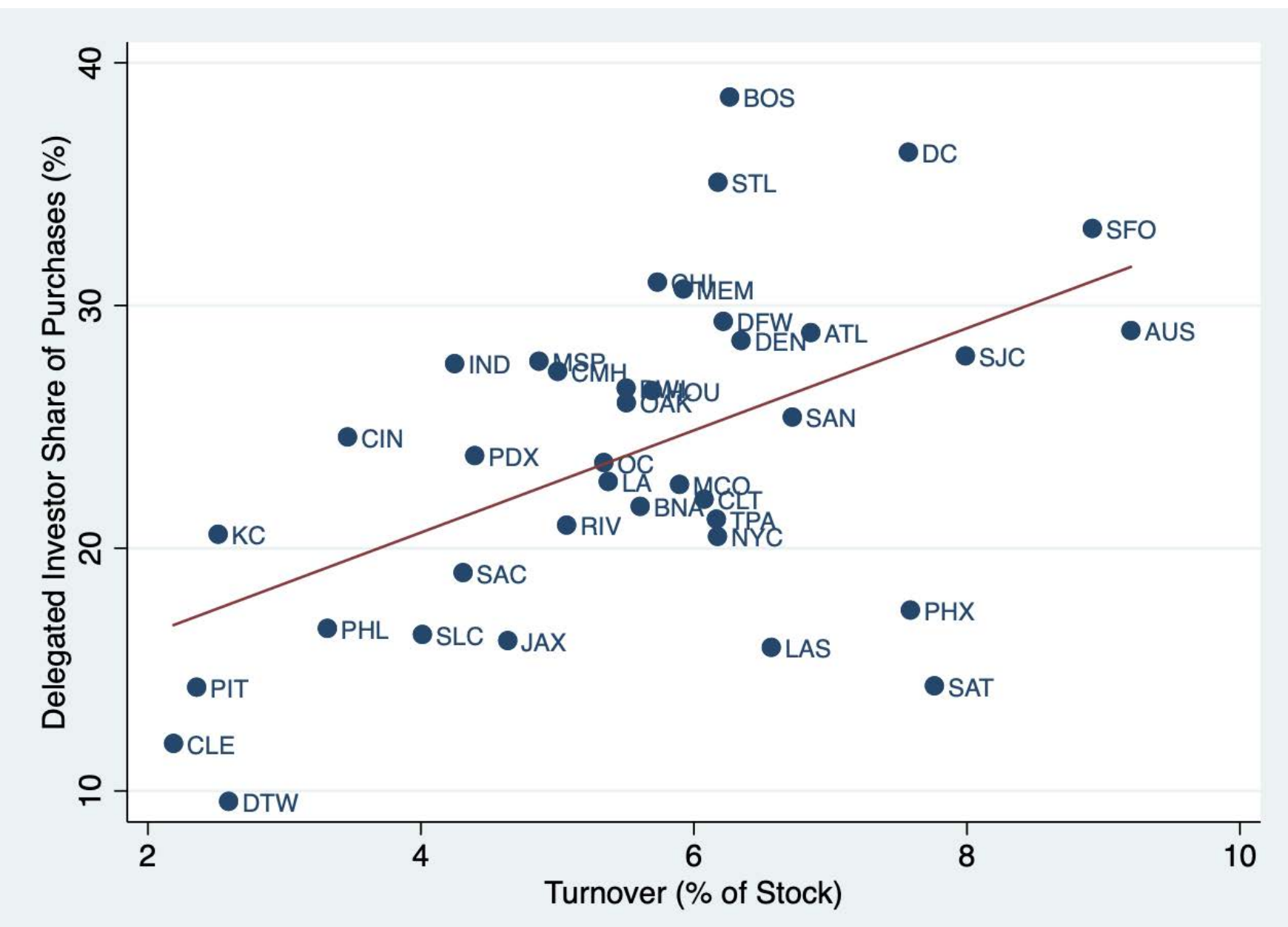

Notes: 1) Delegated Investor shares for each MSA are averaged over 2001-2015. 2) Turnover is annual.

I first explore whether the bivariate relationship in Figure 6 persists at the MSAlevel after controlling for MSA-level characteristics. In addition to preferring credit tenants, 
delegated investors may concentrate their investments in cities that grow faster. I include MSA-level GDP growth as well as controls for factors that the urban economics literature empirically shows predict faster growth in a city over the long run. To the extent that delegated investors are more sophisticated than direct investors, they may be able to such long-term winners. Glaeser (2012) argues that the share of the population with a college degree increases MSA-level growth. ${ }^{7}$ Glaeser et al. (1992) show empirically that cities with more variety across industries and cities with more firm-level competition grow more rapidly. I therefore include college, emp_HHI, and estsperemp as control variables.

The first column of Table 7 controls only for year fixed effects. The coefficient on the share of property transacting in an MSA, $t f$, is 1.74 indicating that a one standard deviation increase in trade frequency is associated with a 6-percentage point increase in the delegated investor share. The second column controls for year fixed effects, city population, and economic fundamentals. The coefficient on $t f$ falls slightly to 1.52 but is still statistically at the $1 \%$ level. Instead of proxying for the availability of credit tenants using establishment-level employment data, column 3 includes the total assets of publicly-traded firms headquartered in the MSA (logfirmassets). Column 4 adds MSA-level GDP growth as a control which reduces the sample size by one year since MSA-level GDP is not available until 2001. The coefficient on GDP growth is negative but far from statistically significant. The coefficient on $t f$ remains similar to that in columns $1-3$. The dependent variable in column 5 is the share of sales by delegated investors instead of the share of purchases. The coefficient falls to 0.91 but remains statistically significant at the $1 \%$ level.

The economic fundamentals included in columns (1)-(5) control for some MSA-level characteristics. However, there are many MSA characteristics that may matter to investors that the regressions do not include. To control for omitted variables specific to a city, I include MSA fixed effects in the final specification in Table 7. In this specification, I include a binary variable that takes a value of one if the observation comes from the years 2001-2007 to control for heterogeneity over time. I do not control for year fixed effects since variation from year-to-year in trade frequency is often idiosyncratic, especially for smaller cities, rather

\footnotetext{
${ }^{7}$ See also Glaeser and Maré (2001), Moretti (2004), and Shapiro (2006).
} 
than indicating persistent differences. Thus, in column 6 the relationship between delegated investor share and trade frequency is identified off variation between the first and second half of the sample within an MSA. The coefficient on trade frequency is of similar magnitude to the benchmark specification in column 2 and remains statistically significant at the $1 \%$ level.

The results in Table 7 provide some support for the credit tenant hypothesis. The coefficient on pubempshare is positive and statistically significant at the $10 \%$ level. The magnitude is such that a one percentage point increase in the share of employment in publicly traded firms increases the delegated investor share by about 0.35 percentage points. Thus, a one standard deviation increase in pubempshare raises the share of delegated investors by about 1.2 percentage points. In column 3, the coefficient on logfirmassets is also positive and statistically significant. The coefficient on college is highly statistically significant in all specifications indicating that delegated investors concentrate their investments in more educated cities.

\subsubsection{Transaction-Level Evidence that Delegated Investors Choose Higher Trade Frequency Cities}

I next explore the relation between trade frequency and delegated investors using transactionslevel data. The advantage of this approach is that I can control for property-level characteristics. I therefore run probit and OLS regressions where the dependent variable takes a value of one if the transaction is made by a delegated investor and zero if the purchase is that of a direct investor. In particular I estimate,

$$
\text { delegated }=\alpha_{0}+\beta t \text { fmeasure }+\Gamma X+\epsilon
$$

where $t$ fmeasure is one of three measures of what an individual investor might expect the trade frequency in a market to be.

I first consider $t f$, which is the overall turnover in that year and MSA. Second, I consider a property-type specific measure, tfavg_bytype. The reason for considering a 
Table 7: Delegated Investor Share and Trade Frequency

\begin{tabular}{|c|c|c|c|c|c|c|}
\hline & $\begin{array}{c}\text { (1) } \\
\text { delshare }\end{array}$ & $\begin{array}{c}(2) \\
\text { delshare }\end{array}$ & $\begin{array}{c}(3) \\
\text { delshare }\end{array}$ & $\begin{array}{c}\text { (4) } \\
\text { delshare }\end{array}$ & $\begin{array}{c}(5) \\
\text { delshare_sell }\end{array}$ & $\begin{array}{c}\text { (6) } \\
\text { delshare }\end{array}$ \\
\hline$t f$ & $\begin{array}{c}1.74^{* * *} \\
(0.36)\end{array}$ & $\begin{array}{c}1.52^{* * *} \\
(0.22)\end{array}$ & $\begin{array}{c}1.56^{* * *} \\
(0.22)\end{array}$ & $\begin{array}{c}1.60^{* * *} \\
(0.21)\end{array}$ & $\begin{array}{c}0.91^{* * *} \\
(0.15)\end{array}$ & $\begin{array}{c}1.65^{* * *} \\
(0.22)\end{array}$ \\
\hline pubempshare & & $\begin{array}{l}0.36^{*} \\
(0.19)\end{array}$ & & $\begin{array}{l}0.34^{*} \\
(0.20)\end{array}$ & $\begin{array}{l}-0.11 \\
(0.13)\end{array}$ & \\
\hline logfirmassets & & & $\begin{array}{l}1.35^{*} \\
(0.69)\end{array}$ & & & \\
\hline emp_HHI & & $\begin{array}{l}-178 \\
(123)\end{array}$ & $\begin{array}{l}-152 \\
(111)\end{array}$ & $\begin{array}{l}-130 \\
(154)\end{array}$ & $\begin{array}{c}-225^{* *} \\
(89.4)\end{array}$ & \\
\hline estsperemp & & $\begin{array}{l}-34.1 \\
(68.9)\end{array}$ & $\begin{array}{l}28.5 \\
(73.1)\end{array}$ & $\begin{array}{l}3.11 \\
(71.4)\end{array}$ & $\begin{array}{c}114 \\
(72.8)\end{array}$ & \\
\hline college & & $\begin{array}{c}0.50^{* * *} \\
(0.13)\end{array}$ & $\begin{array}{c}0.34^{* *} \\
(0.13)\end{array}$ & $\begin{array}{c}0.51^{* * *} \\
(0.14)\end{array}$ & $\begin{array}{c}0.49^{* * *} \\
(0.092)\end{array}$ & \\
\hline gdpgrowth & & & & $\begin{array}{l}-0.10 \\
(0.17)\end{array}$ & & \\
\hline half1 & & & & & & $\begin{array}{l}-1.27 \\
(0.96)\end{array}$ \\
\hline Observations & 578 & 578 & 578 & 541 & 578 & 578 \\
\hline$R^{2}$ & $23.4 \%$ & $26.9 \%$ & $27.1 \%$ & $29.1 \%$ & $22.6 \%$ & $37.5 \%$ \\
\hline Year FEs & Yes & Yes & Yes & Yes & Yes & No \\
\hline Pop Quintiles & No & Yes & Yes & Yes & Yes & No \\
\hline MSA FEs & No & No & No & No & No & Yes \\
\hline
\end{tabular}

Notes: 1) $* * *, * *$, and $*$ indicate $p<0.01, p<0.05$, and $p<0.1$. 2) Dependent variable in columns (1) through (4) is the share of purchases by delegated investors in an MSA in that year. 3) Dependent variable in column (5) is the share of sales by delegated investors in an MSA in that year. 4) $t f$ is percent of property stock transacting in that MSA-year; logfirmassets is the log of the sum of the assets of all publicly-listed firms headquartered in that MSA; gdpgrowth is MSA-level annual GDP growth available 2002-2015; half 1 takes a value of one if the observation is from 2001-2007, zero otherwise. 5) See Table 3 for remaining variable definitions. 6) Standard errors clustered by MSA are in parentheses. 
property-type specific measure is that many investors specialize not just in particular types of cities but also in particular property types. An investor that focuses on industrial property likely does not care about the trade frequency of retail in a city. Because there are often only a few or sometimes no transactions in a particular property type in any particular MSA in a given year, I average this measure over all years in an MSA-property type. Finally, I consider a measure of trade frequency that is predetermined, tfavg_firsthalf, and look only at transactions from the second half of the sample.

The control variables in $X$ include MSA-level economic fundamentals, MSA-level property market characteristics, individual property characteristics, quintiles for city size, quintiles for property size, and quintiles for property age. I include property size controls because delegated investors, who often need to deploy large amounts of capital and have limited resources to carefully examine many properties, may focus their investments on properties where they can deploy a large amount of capital in a single transaction.

As is known from the bond market (see, for example, Edwards et al. (2007) and Green et al. (2007)), higher quality assets usually trade more frequently. It is thus possible that the relationship in Figure 6 merely reflects delegated owners preferring higher quality assets and those assets also being more liquid. In all specifications, I include controls for the general state of that MSA's property market using property type-specific measures of rent growth and occupancy, rentgr_bytype and occrate_bytype and property age quintiles. In some specifications, I also include the RCA property-quality controls.

Table 8 presents the results from estimating equation (1) using a Probit model. The first three columns present the results without the RCA property-quality measures. Each column uses a different measure of the trade frequency an investor could expect in an MSA. In all three specifications, the coefficient on the trade frequency measure is positive and of a similar magnitude. It is statistically significant for $t f$ and $t f a v g \_b y t y p e$.

In Table 8, the coefficients on the MSA-level economic fundamentals are mostly insignificant in contrast to the MSA-level results in Table 7. The coefficient on college is usually positive and is statistically significant in columns 2 and 5 consistent with it having a robust relationship with delegated investor share in Table 7. Rather than credit tenants 
Table 8: Probit Regressions of Investor Type on Trade Frequency

\begin{tabular}{|c|c|c|c|c|c|c|}
\hline & $\overline{(1)}$ & $\overline{(2)}$ & $\overline{(3)}$ & $(4)$ & $\overline{(5)}$ & $\overline{(6)}$ \\
\hline$t f$ & $\begin{array}{c}0.019^{*} \\
(0.010)\end{array}$ & & & $\begin{array}{c}0.019 \\
(0.012)\end{array}$ & & \\
\hline tfavg_bytype & & $\begin{array}{c}0.017^{* * *} \\
(0.0058)\end{array}$ & & & $\begin{array}{l}0.016^{* *} \\
(0.0068)\end{array}$ & \\
\hline tfavg_firsthalf & & & $\begin{array}{c}0.015 \\
(0.012)\end{array}$ & & & $\begin{array}{c}0.041^{* *} \\
(0.017)\end{array}$ \\
\hline pubempshare & $\begin{array}{l}-0.0057 \\
(0.0061)\end{array}$ & $\begin{array}{l}-0.0075 \\
(0.0074)\end{array}$ & $\begin{array}{c}0.0076 \\
(0.0070)\end{array}$ & $\begin{array}{l}-0.0050 \\
(0.0080)\end{array}$ & $\begin{array}{l}-0.0053 \\
(0.0088)\end{array}$ & $\begin{array}{c}0.012 \\
(0.0089)\end{array}$ \\
\hline$e m p_{-} H H I$ & $\begin{array}{l}-4.65 \\
(3.47)\end{array}$ & $\begin{array}{l}-3.81 \\
(3.31)\end{array}$ & $\begin{array}{c}3.60 \\
(4.11)\end{array}$ & $\begin{array}{l}-1.53 \\
(4.07)\end{array}$ & $\begin{array}{l}-0.33 \\
(3.94)\end{array}$ & $\begin{array}{l}9.17^{* *} \\
(4.09)\end{array}$ \\
\hline estsperemp & $\begin{array}{l}-2.69 \\
(3.07)\end{array}$ & $\begin{array}{l}-2.69 \\
(2.98)\end{array}$ & $\begin{array}{c}0.97 \\
(2.28)\end{array}$ & $\begin{array}{l}-5.16 \\
(3.64)\end{array}$ & $\begin{array}{l}-4.90 \\
(3.65)\end{array}$ & $\begin{array}{l}-2.80 \\
(2.48)\end{array}$ \\
\hline college & $\begin{array}{c}0.0056 \\
(0.0036)\end{array}$ & $\begin{array}{c}0.0067^{* *} \\
(0.0032)\end{array}$ & $\begin{array}{c}0.0026 \\
(0.0033)\end{array}$ & $\begin{array}{c}0.0055 \\
(0.0040)\end{array}$ & $\begin{array}{l}0.0072^{*} \\
(0.0038)\end{array}$ & $\begin{array}{c}-0.00033 \\
(0.0036)\end{array}$ \\
\hline occrate_bytype & $\begin{array}{l}0.012^{* *} \\
(0.0056)\end{array}$ & $\begin{array}{l}0.015^{* *} \\
(0.0058)\end{array}$ & $\begin{array}{l}0.014^{* *} \\
(0.0056)\end{array}$ & $\begin{array}{l}0.014^{* *} \\
(0.0059)\end{array}$ & $\begin{array}{c}0.017 * * * \\
(0.0062)\end{array}$ & $\begin{array}{c}0.027^{* * *} \\
(0.0075)\end{array}$ \\
\hline rentgr_bytype & $\begin{array}{c}-0.00073 \\
(0.0012)\end{array}$ & $\begin{array}{c}-0.00049 \\
(0.0013)\end{array}$ & $\begin{array}{c}0.0020 \\
(0.0027)\end{array}$ & $\begin{array}{l}-0.0018 \\
(0.0015)\end{array}$ & $\begin{array}{l}-0.0015 \\
(0.0015)\end{array}$ & $\begin{array}{c}-0.00034 \\
(0.0028)\end{array}$ \\
\hline office & $\begin{array}{c}0.45^{* * *} \\
(0.059)\end{array}$ & $\begin{array}{l}0.40^{* * *} \\
(0.068)\end{array}$ & $\begin{array}{l}0.37^{* * *} \\
(0.061)\end{array}$ & $\begin{array}{c}0.36^{* * *} \\
(0.069)\end{array}$ & $\begin{array}{c}0.32^{* * *} \\
(0.080)\end{array}$ & $\begin{array}{l}0.35^{* * *} \\
(0.081)\end{array}$ \\
\hline industrial & $\begin{array}{c}0.42^{* * *} \\
(0.061)\end{array}$ & $\begin{array}{c}0.50^{* * *} \\
(0.062)\end{array}$ & $\begin{array}{c}0.38^{* * *} \\
(0.066)\end{array}$ & $\begin{array}{c}0.26^{* * *} \\
(0.064)\end{array}$ & $\begin{array}{c}0.32^{* * * *} \\
(0.064)\end{array}$ & $\begin{array}{c}0.14^{*} \\
(0.073)\end{array}$ \\
\hline QScoreLocal & & & & $\begin{array}{c}0.71^{* * *} \\
(0.080)\end{array}$ & $\begin{array}{c}0.73^{* * *} \\
(0.087)\end{array}$ & $\begin{array}{c}0.83^{* * *} \\
(0.11)\end{array}$ \\
\hline QScoreNat & & & & $\begin{array}{c}-0.10 \\
(0.099)\end{array}$ & $\begin{array}{l}-0.14 \\
(0.11)\end{array}$ & $\begin{array}{c}-0.30^{* *} \\
(0.13) \\
\end{array}$ \\
\hline Observations & 43,444 & 43,415 & 24,636 & 34,983 & 34,966 & 19,404 \\
\hline Year FEs & Yes & Yes & Yes & Yes & Yes & Yes \\
\hline Size Pop Age Quintiles & Yes & Yes & Yes & Yes & Yes & Yes \\
\hline Pseudo $R^{2}$ & $7.5 \%$ & $7.6 \%$ & $7.4 \%$ & $9.2 \%$ & $9.2 \%$ & $8.8 \%$ \\
\hline
\end{tabular}

Notes: 1) ${ }^{* * *},{ }^{* *}$, and ${ }^{*}$ indicate $p<0.01, p<0.05$, and $p<0.1$. 2) Dependent variable $=$ 1 if purchase by delegated investor, 0 if purchase by direct. 3) Sample is 2001-2015 purchases by delegated and direct investors. 4) tf is the trade frequency in that MSA-year; tfavg_bytype is the average trade frequency in that MSA and property type; tfavg_firsthalf is the average trade frequency in that MSA over the 2001-2007 period. 5) Size Pop Age Quintiles are quintiles for property age, property size, and MSA population. 6) Standard errors clustered by MSA in parentheses. 
not mattering at the individual transaction level, the insignificance of pubempshare is likely simply due to an MSA's credit tenant base being a weak measure of the share of an individual building occupied by credit tenants. Unfortunately, detailed tenant data is not readily available for the universe of commercial properties in the United States.

In the last three specifications, I include both the local and national property-quality controls. The sample size shrinks as the property-quality measures are only available for a subset of transactions. However, the coefficients on the trade frequency measures in columns 4 and 5 are similar to those in columns 1 and 2. The coefficient in column 6 is about twice

the size of the one in column 3. The coefficient on QScoreLocal is positive and statistically significant at the $1 \%$ level indicating that delegated investors choose higher quality properties within an MSA. They also prefer industrial and office properties relative to retail (the omitted category).

Table 9 presents the results from estimating equation (1) by OLS rather than Probit to both test the robustness of the results and to facilitate interpretation of the coefficients. The coefficients indicate that a one percentage point increase in trade frequency increases the likelihood that the transaction is made by a delegated investor by about 0.6 percentage points. The mean of delegated is 0.34 and, across the 578 MSA-years in the sample, the standard deviation of trade frequency is 3.2 percentage points. Thus, we can conclude that a one standard deviation increase in trade frequency in an MSA increases the likelihood that a delegated investor purchases a property by about $6 \%$. The statistical significance of the coefficients on the trade frequency measures in Table 9 are very similar to those in Table 8.

\subsubsection{Robustness}

Market Power Delegated investors, who may be less likely to be local, may shy away from markets where certain investors have market power due to their size relative to the market. To the extent that buyer concentration is correlated with trade frequency in a market, perhaps because delegated investors are more diversified across markets than direct investors, buyer concentration belongs in $X$ in estimating equation 1 . To consider this possibility, I construct the HHI index of buyers in each city. Table 10 presents the results when I include 
Table 9: OLS Regressions of Investor Type on Trade Frequency

\begin{tabular}{|c|c|c|c|c|c|c|}
\hline & (1) & $(2)$ & (3) & (4) & $(5)$ & (6) \\
\hline tf & $\begin{array}{c}0.0071^{*} \\
(0.0036)\end{array}$ & & & $\begin{array}{l}0.0069^{*} \\
(0.0040)\end{array}$ & & \\
\hline tfavg_bytype & & $\begin{array}{c}0.0065^{* * *} \\
(0.0021)\end{array}$ & & & $\begin{array}{c}0.0057^{* *} \\
(0.0024)\end{array}$ & \\
\hline tfavg_firsthalf & & & $\begin{array}{c}0.0053 \\
(0.0044)\end{array}$ & & & $\begin{array}{l}0.013^{* *} \\
(0.0059)\end{array}$ \\
\hline pubempshare & $\begin{array}{c}-0.0023 \\
(0.0021)\end{array}$ & $\begin{array}{c}-0.0030 \\
(0.0026)\end{array}$ & $\begin{array}{c}0.0025 \\
(0.0025)\end{array}$ & $\begin{array}{l}-0.0024 \\
(0.0026)\end{array}$ & $\begin{array}{c}-0.0025 \\
(0.0030)\end{array}$ & $\begin{array}{c}0.0034 \\
(0.0030)\end{array}$ \\
\hline$e m p \_H H I$ & $\begin{array}{l}-1.53 \\
(1.16)\end{array}$ & $\begin{array}{l}-1.20 \\
(1.10)\end{array}$ & $\begin{array}{c}1.29 \\
(1.43)\end{array}$ & $\begin{array}{l}-0.51 \\
(1.32)\end{array}$ & $\begin{array}{r}-0.076 \\
(1.26)\end{array}$ & $\begin{array}{c}3.15^{* *} \\
(1.39)\end{array}$ \\
\hline estsperemp & $\begin{array}{l}-0.93 \\
(1.06)\end{array}$ & $\begin{array}{l}-0.95 \\
(1.03)\end{array}$ & $\begin{array}{c}0.41 \\
(0.80)\end{array}$ & $\begin{array}{l}-1.85 \\
(1.18)\end{array}$ & $\begin{array}{l}-1.79 \\
(1.19)\end{array}$ & $\begin{array}{l}-0.87 \\
(0.79)\end{array}$ \\
\hline college & $\begin{array}{c}0.0020 \\
(0.0012)\end{array}$ & $\begin{array}{c}0.0024^{* *} \\
(0.0011)\end{array}$ & $\begin{array}{c}0.0011 \\
(0.0011)\end{array}$ & $\begin{array}{c}0.0018 \\
(0.0013)\end{array}$ & $\begin{array}{c}0.0024^{*} \\
(0.0013)\end{array}$ & $\begin{array}{c}7.6 \mathrm{e}-06 \\
(0.0013)\end{array}$ \\
\hline occrate_bytype & $\begin{array}{c}0.0042^{* *} \\
(0.0020)\end{array}$ & $\begin{array}{c}0.0050^{* *} \\
(0.0020)\end{array}$ & $\begin{array}{c}0.0043^{* *} \\
(0.0020)\end{array}$ & $\begin{array}{c}0.0043^{* *} \\
(0.0020)\end{array}$ & $\begin{array}{c}0.0052^{* *} \\
(0.0021)\end{array}$ & $\begin{array}{c}0.0079^{* * *} \\
(0.0027)\end{array}$ \\
\hline rentgr_bytype & $\begin{array}{l}-0.00022 \\
(0.00044)\end{array}$ & $\begin{array}{l}-0.00013 \\
(0.00048)\end{array}$ & $\begin{array}{c}0.00071 \\
(0.00097)\end{array}$ & $\begin{array}{l}-0.00059 \\
(0.00050)\end{array}$ & $\begin{array}{c}-0.00049 \\
(0.00053)\end{array}$ & $\begin{array}{c}-0.00010 \\
(0.00098)\end{array}$ \\
\hline office & $\begin{array}{c}0.15^{* * *} \\
(0.023)\end{array}$ & $\begin{array}{c}0.13^{* * *} \\
(0.026)\end{array}$ & $\begin{array}{c}0.12^{* * *} \\
(0.024)\end{array}$ & $\begin{array}{c}0.11^{* * * *} \\
(0.024)\end{array}$ & $\begin{array}{c}0.094^{* * *} \\
(0.029)\end{array}$ & $\begin{array}{c}0.11^{* * * *} \\
(0.030)\end{array}$ \\
\hline industrial & $\begin{array}{c}0.14^{* * * *} \\
(0.023)\end{array}$ & $\begin{array}{c}0.17^{* * *} \\
(0.023)\end{array}$ & $\begin{array}{c}0.13^{* * *} \\
(0.025)\end{array}$ & $\begin{array}{c}0.079^{* * *} \\
(0.023)\end{array}$ & $\begin{array}{c}0.10^{* * *} \\
(0.023)\end{array}$ & $\begin{array}{l}0.047^{*} \\
(0.025)\end{array}$ \\
\hline QScoreLocal & & & & $\begin{array}{l}0.22^{* * *} \\
(0.030)\end{array}$ & $\begin{array}{c}0.23^{* * * *} \\
(0.030)\end{array}$ & $\begin{array}{l}0.25^{* * *} \\
(0.051)\end{array}$ \\
\hline QScoreNat & & & & $\begin{array}{l}-0.020 \\
(0.034) \\
\end{array}$ & $\begin{array}{l}-0.032 \\
(0.037)\end{array}$ & $\begin{array}{l}-0.073 \\
(0.055) \\
\end{array}$ \\
\hline Observations & 43,444 & 43,415 & 24,636 & 34,983 & 34,966 & 19,404 \\
\hline$R^{2}$ & $9.2 \%$ & $9.2 \%$ & $9.1 \%$ & $10.9 \%$ & $11.0 \%$ & $10.4 \%$ \\
\hline Year FEs & Yes & Yes & Yes & Yes & Yes & Yes \\
\hline Size Pop Age Quintiles & Yes & Yes & Yes & Yes & Yes & Yes \\
\hline
\end{tabular}

Notes: 1) ${ }^{* * *},{ }^{* *}$, and $*$ indicate $p<0.01, p<0.05$, and $p<0.1$. 2) Dependent variable $=$ 1 if purchase by delegated investor, 0 if purchase by direct. 3) Sample is 2001-2015 purchases by delegated and direct investors. 4) tf is the trade frequency in that MSA-year; tfavg_bytype is the average trade frequency in that MSA and property type; tfavg_firsthalf is the average trade frequency in that MSA over the 2001-2007 period. 5) Size Pop Age Quintiles are quintiles for property age, property size, and MSA population. 6) Standard errors clustered by MSA in parentheses. 
this variable. The coefficient on the HHI index is negative but never statistically significant. More importantly for the present paper, the coefficient on the trade frequency measures are little changed from the benchmark specifications in Table 8.

Transfer Tax Rates Pittsburgh in particular has unusually high real estate transfer tax rates. During the 2001-2015 sample period, Pittsburgh and Philadelphia had the highest real estate transfer tax rates in the sample at 4.0\%. In contrast, nine cities had no real estate transfer taxes and 30 cities had a transfer tax rate of less than $1.0 \%$. While a finding that delegated investors do not like Pittsburgh because of the high transfer taxes is consistent with them having a higher preference for liquidity, finding that this is the sole reason investors avoid Pittsburgh is slightly different from the market segmentation story the model of the next section proposes. Table 11 therefore presents the results of the probit regression of delegated on the trade frequency measures and the transfer tax rate in that MSA. The coefficients on the trade frequency variables are quite similar to in the benchmark specification while the coefficients on the transfer tax rates are far from statistically significant. ${ }^{8}$

Outlier Cities Figure 7 explores the robustness of the results to the MSAs included in the sample. It shows the coefficient on tfavg_bytype of the probit regression estimated in column (2) of Table 8 dropping one MSA at a time. The figure illustrates that the results are not heavily influenced by any single MSA. All of the coefficients are statistically significant at the $5 \%$ level and are close to the point estimate of 0.017 from the regression with all thirty-nine MSAs.

\footnotetext{
${ }^{8}$ The tax rates used in this analysis combine state-level and any municipal-level taxes and were obtained by internet search. An appealing idea is to use the transfer tax rates as an instrument for trade frequency. Unfortunately, the correlation between trade frequency and transfer tax rates is quite low, likely because there is little variation in transfer tax rates across most cities.
} 
Table 10: Probit Regressions of Investor Type on Trade Frequency Controlling for Buyer Concentration

\begin{tabular}{|c|c|c|c|c|c|c|}
\hline & 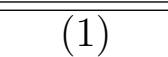 & $\overline{(2)}$ & $(3)$ & (4) & $\overline{(5)}$ & 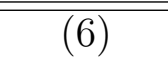 \\
\hline \multirow[t]{2}{*}{$t f$} & $0.019^{*}$ & & & 0.019 & & \\
\hline & $(0.010)$ & & & $(0.012)$ & & \\
\hline \multirow[t]{2}{*}{ tfavg_bytype } & & $0.017^{* * *}$ & & & $0.016^{* *}$ & \\
\hline & & $(0.0059)$ & & & $(0.0070)$ & \\
\hline \multirow[t]{2}{*}{ tfavg_firsthalf } & & & 0.015 & & & $0.040 * *$ \\
\hline & & & $(0.013)$ & & & $(0.017)$ \\
\hline \multirow[t]{2}{*}{ pubempshare } & -0.0057 & -0.0075 & 0.0076 & -0.0051 & -0.0055 & 0.011 \\
\hline & $(0.0060)$ & $(0.0071)$ & $(0.0060)$ & $(0.0079)$ & $(0.0087)$ & $(0.0082)$ \\
\hline \multirow[t]{2}{*}{$e m p \_H H I$} & -4.24 & -3.00 & 5.92 & -1.02 & 0.44 & $10.8^{* * *}$ \\
\hline & (3.98) & $(3.78)$ & $(4.33)$ & $(4.48)$ & $(4.41)$ & $(4.10)$ \\
\hline \multirow{2}{*}{ estsperemp } & -2.61 & -2.55 & 1.35 & -5.11 & -4.83 & -2.62 \\
\hline & $(3.15)$ & $(3.03)$ & $(2.41)$ & $(3.70)$ & $(3.72)$ & $(2.55)$ \\
\hline \multirow[t]{2}{*}{ college } & 0.0061 & $0.0078^{* *}$ & 0.0058 & 0.0062 & $0.0082^{*}$ & 0.0019 \\
\hline & $(0.0045)$ & $(0.0038)$ & $(0.0040)$ & $(0.0046)$ & $(0.0044)$ & $(0.0039)$ \\
\hline \multirow[t]{2}{*}{ occrate_bytype } & $0.012^{* *}$ & $0.015^{* *}$ & $0.013^{* *}$ & $0.014^{* *}$ & $0.016^{* * *}$ & $0.026^{* * *}$ \\
\hline & $(0.0057)$ & $(0.0059)$ & $(0.0060)$ & $(0.0060)$ & $(0.0062)$ & $(0.0077)$ \\
\hline \multirow[t]{2}{*}{ rentgr_bytype } & -0.00069 & -0.00042 & 0.0022 & -0.0018 & -0.0015 & -0.00011 \\
\hline & $(0.0012)$ & $(0.0013)$ & $(0.0027)$ & $(0.0015)$ & $(0.0015)$ & $(0.0028)$ \\
\hline \multirow[t]{2}{*}{ office } & $0.45 * * *$ & $0.40^{* * *}$ & $0.37^{* * *}$ & $0.36^{* * *}$ & $0.31^{* * *}$ & $0.35 * * *$ \\
\hline & $(0.060)$ & $(0.069)$ & $(0.063)$ & $(0.069)$ & $(0.081)$ & $(0.082)$ \\
\hline \multirow[t]{2}{*}{ industrial } & $0.42^{* * *}$ & $0.50^{* * *}$ & $0.39 * * *$ & $0.26^{* * *}$ & $0.32 * * *$ & $0.15^{* *}$ \\
\hline & $(0.061)$ & $(0.062)$ & $(0.066)$ & $(0.063)$ & $(0.064)$ & $(0.071)$ \\
\hline \multirow[t]{2}{*}{ HHIbuyer } & -0.10 & -0.20 & -0.61 & -0.15 & -0.22 & -0.47 \\
\hline & $(0.40)$ & $(0.43)$ & $(0.40)$ & $(0.44)$ & $(0.49)$ & $(0.42)$ \\
\hline \multirow[t]{2}{*}{ QScoreLocal } & & & & $0.70^{* * *}$ & $0.72^{* * *}$ & $0.81^{* * *}$ \\
\hline & & & & $(0.075)$ & $(0.081)$ & $(0.10)$ \\
\hline \multirow[t]{2}{*}{ QScoreNat } & & & & -0.093 & -0.12 & $-0.26^{* *}$ \\
\hline & & & & $(0.094)$ & $(0.11)$ & $(0.12)$ \\
\hline Observations & 43,444 & 43,415 & 24,636 & 34,983 & 34,966 & 19,404 \\
\hline Year FEs & Yes & Yes & Yes & Yes & Yes & Yes \\
\hline Size Pop Age Quintiles & Yes & Yes & Yes & Yes & Yes & Yes \\
\hline Pseudo R-squared & $7.5 \%$ & $7.6 \%$ & $7.4 \%$ & $9.2 \%$ & $9.2 \%$ & $8.8 \%$ \\
\hline
\end{tabular}

Notes: 1) ${ }^{* * *}$, **, and $*$ indicate $p<0.01, p<0.05$, and $p<0.1$. 2) Dependent variable $=$ 1 if purchase by delegated investor, 0 if purchase by direct. 3) Sample is 2001-2015 purchases by delegated and direct investors. 4) tf is the trade frequency in that MSA-year; tfavg_bytype is the average trade frequency in that MSA and property type; tfavg_firsthalf is the average trade frequency in that MSA over the 2001-2007 period. 5) Size Pop Age Quintiles are quintiles for property age, property size, and MSA population. 6) H H Ibuyer is the HHI index of buyer concentration for the MSA calculated over the full sample. 7) Standard errors clustered by MSA in parentheses. 
Table 11: Probit Regressions of Investor Type on Trade Frequency Controlling for Real Estate Transfer Tax Rates

\begin{tabular}{|c|c|c|c|c|c|c|}
\hline & 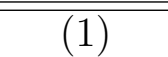 & $\overline{(2)}$ & $(3)$ & (4) & $\overline{(5)}$ & 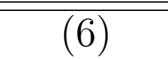 \\
\hline \multirow[t]{2}{*}{$t f$} & $0.018^{*}$ & & & 0.019 & & \\
\hline & $(0.010)$ & & & $(0.012)$ & & \\
\hline \multirow[t]{2}{*}{ tfavg_bytype } & & $0.015^{* *}$ & & & $0.016 * *$ & \\
\hline & & $(0.0062)$ & & & $(0.0071)$ & \\
\hline \multirow[t]{2}{*}{ tfavg_firsthalf } & & & 0.014 & & & $0.041^{* *}$ \\
\hline & & & $(0.012)$ & & & $(0.017)$ \\
\hline \multirow[t]{2}{*}{ pubempshare } & -0.0082 & -0.0088 & 0.0060 & -0.0048 & -0.0046 & 0.013 \\
\hline & $(0.0062)$ & $(0.0073)$ & $(0.0073)$ & $(0.0079)$ & $(0.0086)$ & $(0.0083)$ \\
\hline \multirow[t]{2}{*}{$e m p \_H H I$} & -2.24 & -2.11 & 5.52 & -1.73 & -1.29 & 7.84 \\
\hline & $(3.93)$ & $(3.80)$ & $(4.42)$ & $(4.74)$ & $(4.55)$ & $(4.87)$ \\
\hline \multirow{2}{*}{ estsperemp } & -2.04 & -2.14 & 1.51 & -5.23 & -5.29 & -3.27 \\
\hline & $(3.02)$ & $(2.99)$ & $(2.18)$ & $(3.71)$ & $(3.68)$ & $(2.54)$ \\
\hline \multirow[t]{2}{*}{ college } & $0.0071^{*}$ & $0.0079^{* *}$ & 0.0037 & 0.0053 & 0.0065 & -0.0011 \\
\hline & $(0.0039)$ & $(0.0038)$ & $(0.0036)$ & $(0.0047)$ & $(0.0046)$ & $(0.0041)$ \\
\hline \multirow[t]{2}{*}{ occrate_bytype } & $0.012^{* *}$ & $0.014^{* *}$ & $0.013^{* *}$ & $0.014^{* *}$ & $0.017^{* * *}$ & $0.027^{* * *}$ \\
\hline & $(0.0059)$ & $(0.0060)$ & $(0.0056)$ & $(0.0059)$ & $(0.0060)$ & $(0.0074)$ \\
\hline \multirow[t]{2}{*}{ rentgr_bytype } & -0.00067 & -0.00043 & 0.0019 & -0.0018 & -0.0016 & -0.00033 \\
\hline & $(0.0012)$ & $(0.0013)$ & $(0.0027)$ & $(0.0014)$ & $(0.0015)$ & $(0.0028)$ \\
\hline \multirow[t]{2}{*}{ office } & $0.45 * * *$ & $0.41^{* * *}$ & $0.37^{* * *}$ & $0.36^{* * *}$ & $0.31^{* * *}$ & $0.35 * * *$ \\
\hline & $(0.061)$ & $(0.069)$ & $(0.062)$ & $(0.069)$ & $(0.080)$ & $(0.081)$ \\
\hline \multirow[t]{2}{*}{ industrial } & $0.42^{* * *}$ & $0.49 * * *$ & $0.38 * * *$ & $0.26^{* * *}$ & $0.33^{* * *}$ & $0.14^{*}$ \\
\hline & $(0.061)$ & $(0.064)$ & $(0.067)$ & $(0.065)$ & $(0.065)$ & $(0.072)$ \\
\hline \multirow[t]{2}{*}{ transfertaxrate } & -0.026 & -0.019 & -0.020 & 0.0021 & 0.011 & 0.014 \\
\hline & $(0.023)$ & $(0.026)$ & $(0.020)$ & $(0.028)$ & $(0.031)$ & $(0.024)$ \\
\hline \multirow[t]{2}{*}{ QScoreLocal } & & & & $0.71^{* * *}$ & $0.73^{* * *}$ & $0.83^{* * *}$ \\
\hline & & & & $(0.082)$ & $(0.087)$ & $(0.11)$ \\
\hline \multirow[t]{2}{*}{ QScoreNat } & & & & -0.10 & -0.13 & $-0.29 * *$ \\
\hline & & & & $(0.10)$ & $(0.11)$ & $(0.12)$ \\
\hline Observations & 43,444 & 43,415 & 24,636 & 34,983 & 34,966 & 19,404 \\
\hline Year FEs & Yes & Yes & Yes & Yes & Yes & Yes \\
\hline Size Pop Age Quintiles & Yes & Yes & Yes & Yes & Yes & Yes \\
\hline Pseudo- $R^{2}$ & $7.6 \%$ & $7.6 \%$ & $7.4 \%$ & $9.2 \%$ & $9.2 \%$ & $8.8 \%$ \\
\hline
\end{tabular}

Notes: 1) ${ }^{* * *}$, **, and $*$ indicate $p<0.01, p<0.05$, and $p<0.1$. 2) Dependent variable $=$ 1 if purchase by delegated investor, 0 if purchase by direct. 3) Sample is 2001-2015 purchases by delegated and direct investors. 4) tf is the trade frequency in that MSA-year; tfavg_bytype is the average trade frequency in that MSA and property type; tfavg_firsthalf is the average trade frequency in that MSA over the 2001-2007 period. 5) Size Pop Age Quintiles are quintiles for property age, property size, and MSA population. 6) transfertaxrate is the combined state and city real estate transfer tax rate in percent. 7) Standard errors clustered by MSA in parentheses. 
Figure 7: Coefficients on Trade Frequency in Regressions Dropping one MSA at a Time

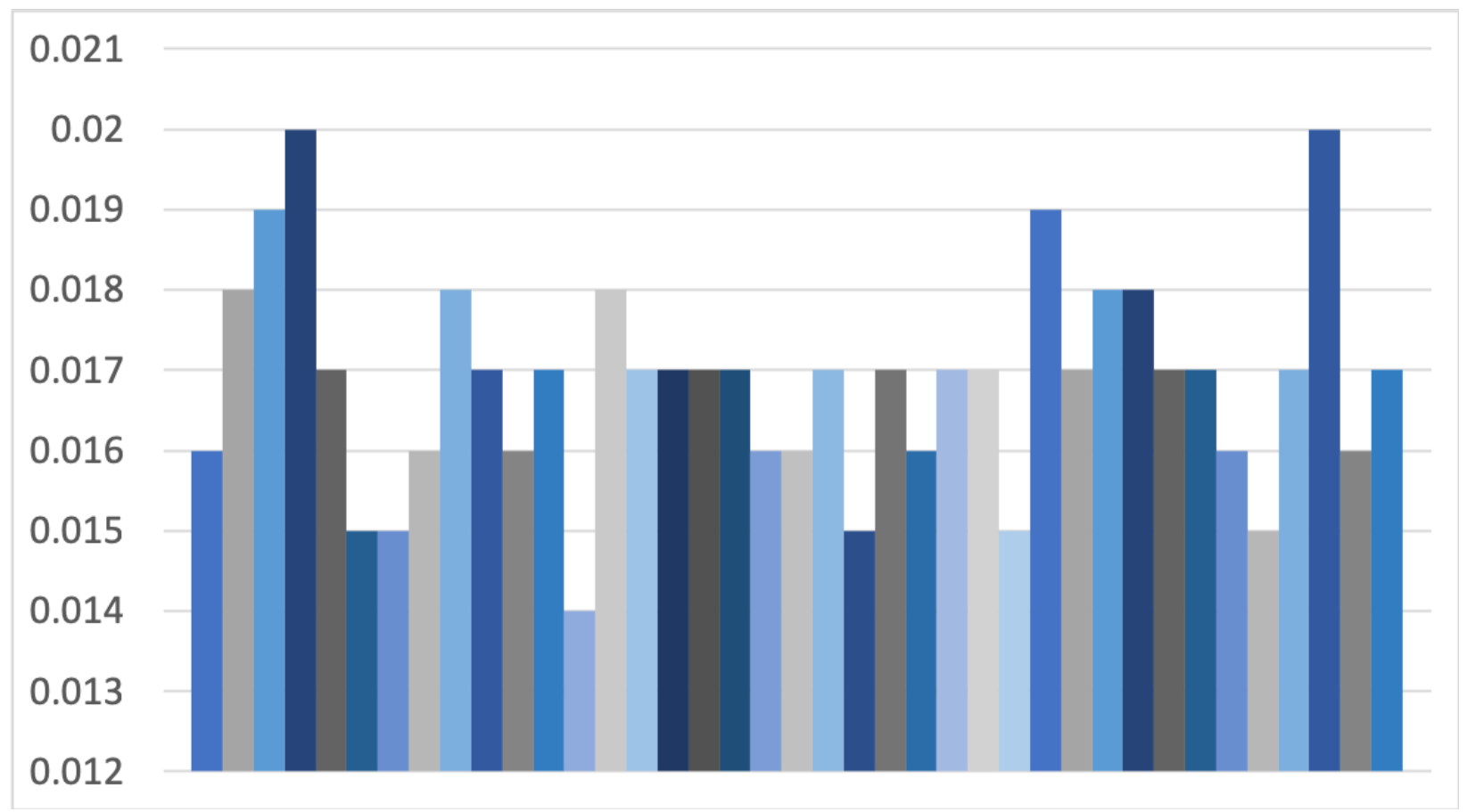

Notes: 1) Each bar represents the coefficient from a regression dropping a single MSA in the regression in column (2) of Table 8. 2) All coefficients are statistically significant at the $5 \%$ level. 


\subsection{Trade Frequency and Cap Rates}

Figure 8 shows that, in general, cap rates are lower in MSAs in which trade is more frequent. This is consistent with there being an illiquidity premium for CRE. However, cap rates do not vary as much across MSAs as turnover does. The range of average cap rates across cities is only two percentage points. In contrast, average annual turnover across MSAs ranges from two to nine percent of the stock. While a full analysis of the differences in cap rates across MSAs is beyond the scope of this paper, the finding that cap rates are higher in cities with lower trade frequency is consistent with the model below.

Figure 8: Cap Rates and Trade Frequency are Inversely Related

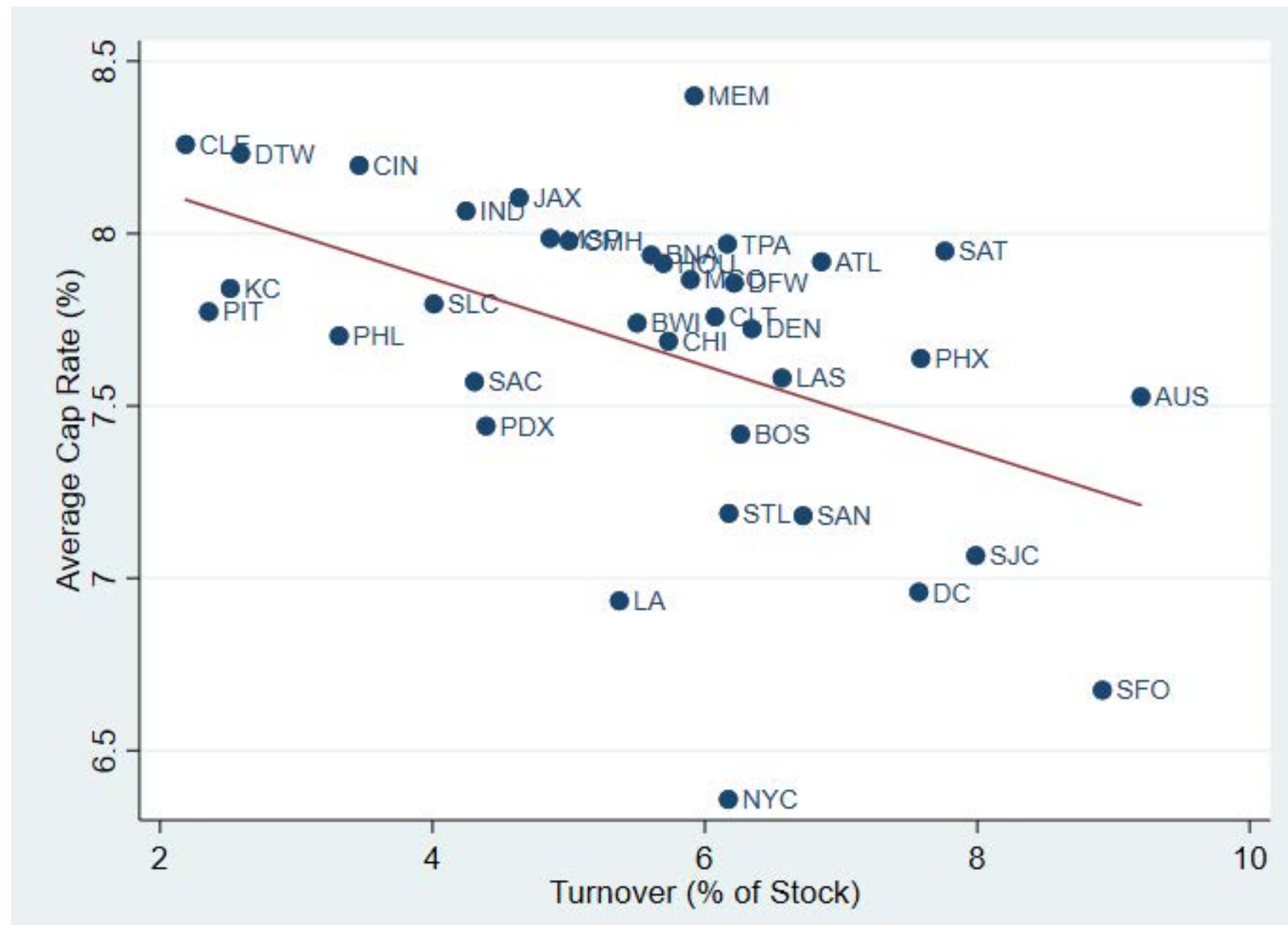

Notes: 1) Cap rates for each MSA are averaged over 2001-2015. 


\section{Explaining the Facts}

I explain the facts above by calibrating a version of Vayanos and Wang (2007) to the US CRE Market. I model delegated investors in CRE as more likely to have liquidity shocks than direct investors. For the model to have relevant empirical predictions, delegated investors need only have a higher average concentration of investors with frequent liquidity shocks; both delegated and direct investors can be individuals who frequently get valuation shocks and thus have high liquidity needs.

\subsection{Model}

There are two assets, 1 and 2, traded in markets 1 and 2. Both assets pay a dividend of 1 per period and are in supply S. The two markets are ex ante identical. Investors must commit to searching in only one market at any given time. In the context of CRE, one may interpret such a restriction as a high cost of acquiring information about a particular city's property market that prevents an investor from searching simultaneously in all possible markets.

Investors are risk-neutral and have a rate of time preference of $r$. Each period, there is an inflow of new agents into the economy. Investors are born into the market without the asset and enjoying a high valuation of the asset, i.e., their per period benefit is the full dividend of 1 . Their valuation of the asset can switch to a low valuation in which case their per period benefit of owning the asset is $1-x$. In contrast to Duffie et al. (2005) and Duffie et al. (2007), once an agent becomes a low valuation agent, it remains a low valuation agent until it sells the property. Once it has sold the property, it exits the economy. Agents that become low valuation agents without having bought a property also exit the economy.

Agents differ in the likelihood that they will receive a valuation shock. Valuation shocks arrive at Poisson rate $\kappa$. The density of investors that enter the economy is $f(\kappa)$, which I take as the uniform distribution over the interval $[\underline{\kappa}, \bar{\kappa}]$.

These assumptions in turn imply that the density of all high valuation agents in the 
economy (rather than that of new entrants to the economy) is

$$
g(\kappa)=\frac{1}{\kappa}
$$

such that $D_{h}$, the measure of high-valuation ages is $\frac{\log (\bar{\kappa})-\log (\underline{\kappa})}{\bar{\kappa}-\underline{\kappa}}$. I focus on the case where there is neither excess demand nor excess supply such that

$$
S=\frac{D_{h}}{2}=0.5 * \frac{\log (\bar{\kappa})-\log (\underline{\kappa})}{\bar{\kappa}-\underline{\kappa}}
$$

When a buyer (a newly born agent) meets a seller (an agent that had bought the asset as a high valuation agent but who now only gets $1-x$ from owning the asset), they use bilateral bargaining to split the gains from trade. In particular, one party is randomly selected to make a take-it-or-leave-it offer. The probability that the buyer is selected to make the offer is $\frac{z}{1+z}, z \in(0, \infty)$.

Buyers and sellers meet randomly within each market. Given total masses of buyers and sellers in market $i, \mu_{B}^{i}$ and $\mu_{S}^{i}$, the matching function $M\left(\mu_{B}^{i}, \mu_{S}^{i}\right)=\lambda \mu_{B}^{i} \mu_{S}^{i}$ characterizes the search technology. It features increasing returns to scale consistent with the intuition that matching is easier in markets with large masses of both buyers and sellers. The parameter $\lambda$ can be thought of as capturing the efficiency of the search technology.

\subsection{Equilibrium}

I focus on the clientele equilibrium in which high $\kappa$ agents choose to enter the high liquidity market, which I take as market 1 without loss of generality. ${ }^{9}$ Let $\mu_{B}^{i}(\kappa), \mu_{O}^{i}(\kappa)$, and $\mu_{S}^{i}(\kappa)$ denote the density of agents with valuation shock frequency $\kappa$ in market $i$ who are looking to buy the asset, who own the asset and remain high valuation, and who own the asset but have become low valuation such that they are looking to sell the asset. The total masses of

\footnotetext{
${ }^{9}$ Vayanos and Wang (2007) show that there also exists a continuum of symmetric equilibria in which the measure of sellers is the same across both markets. In addition to being indeterminate, these equilibria are inconsistent with the empirical facts in Section 3.
} 
such agents in the economy are then

$$
\begin{aligned}
& \int_{\underline{\kappa}}^{\bar{\kappa}} \mu_{B}^{i}(\kappa) d \kappa=\mu_{B}^{i} \\
& \int_{\underline{\kappa}}^{\bar{\kappa}} \mu_{O}^{i}(\kappa) d \kappa=\mu_{O}^{i} \\
& \int_{\underline{\kappa}}^{\bar{\kappa}} \mu_{S}^{i}(\kappa) d \kappa=\mu_{S}^{i}
\end{aligned}
$$

By Lemma 1 of Vayanos and Wang (2007), there is a unique value of $\kappa, \kappa^{*}$, such that all investors with $\kappa>\kappa^{*}$ choose to enter market 1 and all investors with $\kappa<\kappa^{*}$ go to market 2. Given this fact, to determine $\mu_{B}^{1}$ (for example), I use the fact that the inflow of buyers into market 1 is $\frac{1}{\bar{\kappa}-\kappa} d \kappa$ for $\kappa>\kappa^{*}$ and 0 for $\kappa<\kappa^{*}$ while the outflow is $\lambda \mu_{B}^{1}(\kappa) \mu_{S}^{i} d \kappa$. This gives an equation for $\mu_{B}^{i}(\kappa)$ in terms of $\mu_{S}^{i}$ and the parameters. I similarly set the inflow into owners equal to the outflow for a given $\kappa$ to solve for $\mu_{O}^{i}$ in terms of $\mu_{S}^{i}$ and the underlying parameters. Finally, I impose that the mass of owners and sellers must equal total supply in each market (i.e., $\mu_{O}^{i}+\mu_{S}^{i}=S$ ).

The equilibrium of the model then requires the following three equations to be solved for the three unknowns $\mu_{S}^{1}, \mu_{S}^{2}$, and $\kappa^{*}$ :

$$
\begin{aligned}
& \frac{1}{\bar{\kappa}-\underline{\kappa}} \int_{\kappa^{*}}^{\bar{\kappa}} \frac{\lambda \mu_{S}^{1}}{k\left(k+\lambda \mu_{S}^{1}\right)} d k+\mu_{S}^{1}=S \\
& \frac{1}{\bar{\kappa}-\underline{\kappa}} \int_{\underline{\kappa}}^{\kappa^{*}} \frac{\lambda \mu_{S}^{2}}{k\left(k+\lambda \mu_{S}^{2}\right)} d k+\mu_{S}^{2}=S \\
& \mu_{S}^{1}-\mu_{S}^{2}+\mu_{S}^{1} \frac{1}{2\left(r+\kappa^{*}\right)(\bar{\kappa}-\underline{\kappa})} \int_{\underline{\kappa}}^{\kappa^{*}} \frac{\lambda\left(r+\kappa^{*}+0.5 \lambda \mu_{S}^{2}\right)}{\left(k+\lambda \mu_{S}^{2}\right)\left(r+k+0.5 \lambda \mu_{S}^{2}\right)} d k \\
& +\mu_{S}^{2} \frac{1}{2\left(r+\kappa^{*}\right)(\bar{\kappa}-\underline{\kappa})} \int_{\kappa^{*}}^{\bar{\kappa}} \frac{\lambda\left(r+\kappa^{*}+0.5 \lambda \mu_{S}^{1}\right)}{\left(k+\lambda \mu_{S}^{1}\right)\left(r+k+0.5 \lambda \mu_{S}^{1}\right)} d k=0
\end{aligned}
$$

Trading volume in the model is determined entirely by the parameters $\underline{\kappa}, \bar{\kappa}$, and $\lambda$. Trading volume does not depend on the discount from a liquidity shock, $x$. $x$ matters only for price determination.

Transaction prices are heterogeneous in each market. While transaction prices have closed form solutions, in the interests of space, I do not reproduce the expressions for them 
from Vayanos and Wang (2007). Section 4.3 presents the average cap rates in markets 1 and 2 as these are the analogues to the empirical MSA averages. See Vayanos and Wang (2007) for additional details on the model solution.

\subsection{Calibration}

Given that the model has no role for heterogeneity in liquidity needs or technologies over time, I collapse the data to the means for each of the 39 MSAs. I then split the sample of cities into two sets of cities, high and low turnover. High turnover cities are the top half of cities by turnover. Table 12 shows that the most liquid cities have turnover of $6.85 \%$ while the least liquid cities have turnover of just $4.30 \%$. The difference in turnover between the two sets of cities is more than $45 \%$ of the mean level of turnover. By comparison, the difference in the average cap rates across the two sets of cities is a mere 13 basis points or less than $2 \%$ of the average cap rate.

I fix $z$ to 1 such that buyers and sellers have equal bargaining weight since the data provides no guidance on the relative bargaining weights. I choose the other five parameters of the model, $r, \underline{\kappa}, \bar{\kappa}, \lambda$, and $x$ to match the data. I aim to match five moments in the data: Turnover in high and low turnover markets, cap rates in high and low turnover markets, and the average time to sell in the US across all cities. I target an average time on the market of 11 months consistent with CoStar (2018)'s estimates for 2007-2018, the only years for which I could find a publicly available estimate of time-on-the-market for the CRE market.

I set $r$ at $5.45 \%$ which is considerably higher than the average yield on the 10-year US Treasury over 2001-2015. The risk-free rate in the model must be higher to match the data because, in the model, there is no credit risk. Given the other moments in the data, the model fits the data relatively well by setting $\underline{\kappa}, \bar{\kappa}, \lambda$, and $x$ to $0.035,0.09,2.6$, and 0.40 . The midpoint of the range of $\kappa$ is such that each high valuation agent faces a $6.25 \%$ chance of getting a liquidity shock in any given year and thus becoming a low valuation agent.

For these parameter values, the value of $\kappa$ that separates the two sets of agents is $\kappa^{*}=0.056$. As Vayanos and Wang (2007) point out, there are both more buyers and more 
Table 12: Search Model with Investor Heterogeneity

\begin{tabular}{|c|c|c|c|c|c|}
\hline & \multicolumn{3}{|c|}{ Data: US Cities } & \multicolumn{2}{|c|}{ Model } \\
\hline & All & High Turnover & Low Turnover & $\begin{array}{l}\text { High Turnover } \\
\text { Market }\left(\kappa>\kappa^{*}\right)\end{array}$ & $\begin{array}{l}\text { Low Turnover } \\
\text { Market }\left(\kappa \leqslant \kappa^{*}\right)\end{array}$ \\
\hline Avg. Price & & & & 13.3 & 12.9 \\
\hline Avg. Cap Rate & $7.63 \%$ & $7.51 \%$ & $7.74 \%$ & $7.49 \%$ & $7.73 \%$ \\
\hline Turnover & $5.54 \%$ & $6.85 \%$ & $4.30 \%$ & $6.78 \%$ & $4.27 \%$ \\
\hline Del. Share & $23.9 \%$ & $21.2 \%$ & $26.7 \%$ & & \\
\hline $\mathrm{N}$ & 39 & 19 & 20 & & \\
\hline$\mu_{B}$ & & & & 0.48 & 0.37 \\
\hline$\mu_{O}$ & & & & 8.12 & 8.20 \\
\hline$\mu_{S}$ & & & & 0.46 & 0.38 \\
\hline Mos. to Sell & 11 & & & 9.6 & 12.6 \\
\hline & & & & & 56 \\
\hline Illiquidity Premium (bp) & & & & 204 & 228 \\
\hline Illiquidity Price Discount & & & & $27.2 \%$ & $29.5 \%$ \\
\hline
\end{tabular}

Notes: 1) $\kappa^{*}$ is the unique value in the distribution of $\kappa$ such that investors with values of $\kappa$ above that choose to search in market 1 (high turnover) and investors with values of $\kappa$ below that choose to search in market 2 (low turnover). 2) Mos. to sell is the expected number of months a seller expects to wait before finding a buyer. 3) The data on cap rates, turnover, and delegated investor shares from US cities covers 2001-2015. 4) The Mos. to Sell is approximate and covers the entire US CRE market for 2007-2018. 5) The illiquidity premium is the spread above Treasuries for investing in illiquid CRE with the same credit risk as Treasuries. 6) The dividend is $\$ 1$ every period such that the frictionless price would be $\frac{1}{r}=\$ 18.35$. 
sellers in the more liquid market. The equilibrium masses of buyers in markets 1 and 2 are 0.48 and 0.37 such that the equilibrium times on the market $\left(\frac{1}{\lambda \mu_{B}^{i}}\right)$ are approximately 10 and 13 months. $^{10}$

The differences in cap rates between the high and low turnover markets is very small, a mere 23 basis points. In practice, the cash flows of CRE may differ across cities, which would generate additional heterogeneity in cap rates. The lack of credit risk in the model is also why I calibrate the model with a higher risk-free rate than that in the data. The model generates small relative illiquidity premia because of the heterogeneity in how investors value liquidity. Although the illiquidity premium across markets is positive, those investors that don't place a high value on liquidity choose the illiquid market and do not have to be paid a lot to do so. In contrast, if investors were homogeneous in their liquidity preferences, the illiquidity premium would have to be higher to get to an equilibrium in which there is no excess supply of the asset in the less liquid market.

Overall, however, the model implies that CRE sells at a 27-30\% discount relative to a perfectly liquid, risk-free asset or offers two percentage points compensation in yield for its illiquidity inherent. While the model is highly stylized, this is the first estimate of the illiquidity premium of CRE in the literature. ${ }^{11}$ In the housing market, Piazzesi et al. (Forthcoming) report "frictional" price discounts of between 10-40\% of the price of a property. ${ }^{12}$ Consistent with real estate being much less liquid than financial securities, this is a substantially higher illiquidity return premium than what the literature finds for funds that hold financial securities. Aragon (2007) reports a 4-7\% percent higher return on hedge funds with lockup restrictions relative to unrestricted funds. Barth and Monin (2018) construct a measure of illiquidity based on the average number of days it would take to liquidate a portfolio. Using this measure and data from hedge funds' security holdings, they find an

\footnotetext{
${ }^{10}$ See Carrillo (2013) and Carrillo and Pope (2012) for discussions of time on the market as a measure of liquidity in the residential market.

${ }^{11}$ Fisher et al. (2003) adjust CRE returns for differences in the ability to quickly sell a property at different points in the CRE cycle.

${ }^{12}$ In part because they allow for heterogeneity in search over other dimensions of the property (e.g., number of bathrooms), and because potential buyers do not sort solely along the liquidity of the segment as they do here, Piazzesi et al. (Forthcoming) find much larger differences in illiquidity discounts across segments than what I find in the CRE market.
} 
illiquidity premium of 82 basis points per year per additional log-day of illiquidity. Khandani and Lo (2011) estimate illiquidity premia of $2.74 \%$ to $9.91 \%$ in hedge funds and mutual funds.

\section{Conclusions}

This paper has shown that the composition of the investor base in CRE differs markedly across cities. Delegated investors, who are more likely to have shorter holding periods, are more prevalent in markets with higher turnover. The shorter average holding period of delegated investors is not just due to their larger size. Rather, the greater need for liquidity arises from the agency issues associated with managing outside money. From the perspective of a delegated investor, the problem with Pittsburgh and similar cities is that they lack liquidity. The low share of delegated investors in markets like Pittsburgh is itself a reason that CRE in Pittsburgh trades infrequently. Finally, delegated investors prefer to invest in larger assets, in cities where a larger fraction of the work force is employed by a publicly traded firm, and in highly educated cities.

A directed search model with heterogeneity in the frequency with which investors get liquidity shocks can explain the relationship between trade frequency and investor composition. In the model, CRE markets are ex ante homogeneous and yet one market emerges as having more liquidity and lower returns than the other. In practice, there are likely some initial differences across CRE markets that give one set of cities an edge in attracting investors that have a greater need for liquidity. The model highlights that there is path dependency in liquidity and thus the ability of a city to attract certain types of capital. There are likely consequences of being unable to attract delegated investors, who prefer larger buildings, for urban design and thus the ability to attract certain types of workers. I leave to future research the question of the consequences for cities of being unable to attract delegated investors due to path dependency in investor composition.

The findings illustrate how path dependence arises in the definition of institutional-

quality assets. Part of what makes an asset institutional-quality is the existing concentration 
of institutions in its investor base. Given how investor preferences for liquidity and the liquidity of a market reinforce one another, a market needs to have a critical mass of investors with similar liquidity preferences for it to attract investors that will in turn generate higher trade frequency.

One limitation of the model is that it assumes that liquidity shocks are idiosyncratic. In practice, shocks to liquidity may be correlated across investors. Furthermore, different types of investors may have different correlations among their liquidity shocks. It seems plausible, for example, that herding behavior among delegated investors increases the correlation of their liquidity shocks. I leave the modeling and measurement of correlation in liquidity shocks within markets and investor types to future work.

\section{References}

Admati, A. R. And P. Pfleiderer (1988): "A Theory of Intraday Patterns: Volume and Price Variability," Review of Financial Studies, 1, 3-40.

Andonov, A., P. Eichholtz, And N. KoK (2015): "Intermediated Investment Management in Private Markets: Evidence from Pension Fund Investments in Real Estate," Journal of Financial Markets, 22, 73-103.

Andonov, A. And J. D. Rauh (2018): "The Return Expectations of Institutional Investors," Working Paper, Stanford University.

Aragon, G. O. (2007): "Share Restrictions and Asset Pricing: Evidence from the Hedge Fund Industry," Journal of Financial Economics, 83, 33-58.

Badarinza, C., T. Ramadorai, And C. Shimizu (2018): "Gravity, Counterparties, and Foreign Investment," Working Paper, National University of Singapore.

Barth, D. And P. Monin (2018): "Illiquidity in Intermediary Portfolios: Evidence from Large Hedge Funds," Working Paper, Office of Financial Research, US Department of the Treasury. 
Biais, B. And R. C. Green (2007): "The Microstructure of the Bond Market in the 20th Century," Working Paper, Toulouse School of Economics.

Cannon, S. E. And R. A. Cole (2011): "How Accurate Are Commercial Real Estate Appraisals? Evidence from 25 Years of NCREIF Sales Data," The Journal of Portfolio Management, 37, 68-88.

Carrillo, P. E. (2013): "To Sell or Not to Sell: Measuring the Heat of the Housing Market," Real Estate Economics, 41, 310-346.

Carrillo, P. E. And J. C. Pope (2012): "Are Homes Hot or Cold Potatoes? The Distribution of Marketing Time in the Housing Market," Regional Science and Urban Economics, 42, 189-197.

Chakraborty, I. And M. Ewens (2018): "Managing Performance Signals Through Delay: Evidence from Venture Capital," Management Science, 64, 2875-2900.

Chang, B. (2018): "Adverse Selection and Liquidity Distortion," Review of Economic Studies, 85, 275-306.

CoStar (2018): "CoStar Composite Price Indices Extend Moderate Annual Growth Trend Despite Summer Slowdown," Note, https://www.costargroup.com/costarnews/details/costar-composite-price-indices-extend-moderate-annual-growth-trenddespite-summer-slowdown. Last accessed June 3, 2019.

Costello, J. (2017): "CMBS Investors Not Compromising Quality as Investors Chase Yields," Commercial RealEstate Direct.

Del Guercio, D. (1996): "The Distorting Effect of the Prudent-Man Laws on Institutional Equity Investments," Journal of Financial Economics, 40, 31-62.

Duffie, D., N. GÂrleanu, And L. H. Pedersen (2005): "Over-the-Counter Markets," Econometrica, 73, 1815-1847. 
- (2007): "Valuation in Over-the-Counter Markets," Review of Financial Studies, 20, $1865-1900$.

Edwards, A. K., L. E. Harris, And M. S. Piwowar (2007): "Corporate Bond Market Transaction Costs and Transparency," The Journal of Finance, 62, 1421-1451.

Fisher, J., D. Gatzlaff, D. Geltner, And D. Haurin (2003): "Controlling for the Impact of Variable Liquidity in Commercial Real Estate Price Indices," Real Estate Economics, 31, 269-303.

García, D. AND Ø. Norli (2012): "Geographic Dispersion and Stock Returns," Journal of Financial Economics, 106, 547-565.

Glaeser, E. (2012): Triumph of the City: How Our Greatest Invention Makes Us Richer, Smarter, Greener, Healthier, and Happier, New York, New York: Penguin.

Glaeser, E. And D. C. Maré (2001): "Cities and Skills," Journal of Labor Economics, 19, 316-342.

Glaeser, E. L., H. D. Kallal, J. A. Scheinkman, And A. Shleifer (1992): "Growth in Cities," Journal of Political Economy, 100, 1126-1152.

Green, R., B. Hollifield, And N. Schürhoff (2007): "Financial Intermediation and the Costs of Trading in an Opaque Market," Review of Financial Studies, 20, 275-314.

Han, L. And W. Strange (2015): "The Microstructure of Housing Markets: Search, Bargaining, and Brokerage," in Handbook of Regional and Urban Economics, ed. by G. Duranton, V. Henderson, and W. Strange, Elsevier, vol. 5, chap. 13, 813-886.

Khandani, A. E. And A. W. Lo (2011): "Illiquidity Premia in Asset Returns: An Empirical Analysis of Hedge Funds, Mutual Funds, and US Equity Portfolios," Quarterly Journal of Finance, 1, 205-264.

Koijen, R. And M. Yogo (Forthcoming): "A Demand System Approach to Asset Pricing," Journal of Political Economy. 
Moretti, E. (2004): "Estimating the Social Return to Higher Education: Evidence from Longitudinal and Repeated Cross-sectional Data," Journal of Econometrics, 121, 175-212.

Mühlhofer, T. (2019): "They Would If They Could: Assessing the Bindingness of the Property Holding Constraints for REITs," Real Estate Economics, 47, 431-477.

Pagano, M. (1989): "Trading Volume and Asset Liquidity," Quarterly Journal of Economics, 104, 255-274.

Piazzesi, M., M. Schneider, And J. Stroebel (Forthcoming): "Segmented Housing Search," American Economic Review.

Plante, S. (2017): "Should Corporate Bond Trading be Centralized," Working Paper, University of Wisconsin-Madison.

SAGI, J. (2017): “Asset-level Risk and Return in Commercial Real Estate Returns," Working Paper, University of North Carolina-Chapel Hill.

Shapiro, J. (2006): "Smart Cities: Quality of Life, Productivity, and the Growth Effects of Human Capital," Review of Economics and Statistics, 88, 324-335.

Starks, L., P. Venkat, And Q. Zhu (2018): "Corporate ESG Profiles and Investor Horizons," Working Paper, University of Texas-Austin.

Stein, J. C. (1989): "Efficient Capital Markets, Inefficient Firms: A Model of Myopic Corporate Behavior," The Quarterly Journal of Economics, 104, 655-669.

VAyanos, D. And T. WAng (2007): "Search and Endogenous Concentration of Liquidity in Asset Markets," Journal of Economic Theory, 136, 66-104. 